\title{
3D gravity inversion and thermodynamic modelling reveal properties of shallow silicic magma reservoir beneath Laguna del Maule, Chile
}

\author{
Craig A. Miller ${ }^{a, b, *}$, Glyn Williams-Jones ${ }^{\mathrm{a}}$, Dominique Fournier ${ }^{\mathrm{c}}$, Jeff Witter ${ }^{\mathrm{d}}$ \\ ${ }^{a}$ Department of Earth Sciences, Simon Fraser University, 8888 University Drive, Burnaby, \\ $B C$ V5A 1S6, Canada \\ ${ }^{b}$ GNS Science, Wairakei Research Centre, Private Bag 2000, Taupo, 3352, New Zealand \\ ${ }^{c}$ Department of Earth and Ocean Sciences, University of British Columbia, Vancouver, BC \\ V6T 1Z4, Canada \\ ${ }^{d}$ Mira Geoscience, 512B 409 Granville St, Vancouver, BC V6C 1T2, Canada. Now at \\ Innovate Geothermal, 104 - 445 West 2nd Avenue, Vancouver, BC V5Y 0E8, Canada
}

\begin{abstract}
Active, large volume, silicic magma systems are potentially the most hazardous form of volcanism on Earth. Knowledge of the location, size, and physical properties of silicic magma reservoirs, is therefore important for providing context in which to accurately interpret monitoring data and make informed hazard assessments. Accordingly, we present the first geophysical image of the Laguna del Maule volcanic field magmatic system, using a novel 3D inversion of gravity data constrained by thermodynamic modelling. The joint analysis of gravity and thermodynamic data allows for a rich interpretation of the magma system, and highlights the importance of considering the full thermodynamic effects on melt density, when interpreting gravity models of active magmatic systems. We image a $30 \mathrm{~km}^{3}$, low density, volatile rich magma reservoir, at around $2 \mathrm{~km}$ depth, containing at least $85 \%$ melt, hosted within a broader $115 \mathrm{~km}^{3}$ body interpreted as wholly or partially crystallised (>70 \% crystal) cumulate mush. Our model suggests a magmatic system with shallow, crystal poor magma, overlying deeper, crystal rich magma. Even though a large density contrast (-600 $\mathrm{kg} / \mathrm{m}^{3}$ ) with the surrounding crust exists, the lithostatic load is $50 \%$ greater
\end{abstract}

\footnotetext{
* Corresponding author

Email address: c.miller@gns.cri.nz (Craig A. Miller)
}

Preprint submitted to Earth and Planetary Science Letters

November 2, 2016

(C) 2016. This manuscript version is made available under the Elsevier user license http://www.elsevier.com/open-access/userlicense/1.0/ 
than the magma buoyancy force, suggesting buoyancy alone is insufficient to trigger an eruption. The reservoir is adjacent to the inferred extension of the Troncoso fault and overlies the location of an intruding sill, driving present day deformation. The reservoir is in close proximity to the $2.0 \mathrm{~km}^{3}$ Nieblas $(r l n)$ eruption at 2-3 ka, which we calculate tapped approximately $7 \%$ of the magma reservoir. However, we suggest that the present day magma system is not large enough to have fed all post-glacial eruptions, and that the location, or size of the system may have migrated or varied over time, with each eruption tapping only a small aliquot of the available magma. The presence of a shallow reservoir of volatile rich, near liquidus magma, in close proximity to regional scale faulting, has important implications for volcano monitoring and hazard mitigation.

Keywords: Bouguer gravity, inversion, MELTS, rhyolite, thermodynamics, volatiles

\section{Introduction}

Accumulation of large volumes of silicic magma in the crust is a pre-requisite to Earth's most dangerous style of volcanic eruption (Cashman and Giordano, 2014). Detailed knowledge of the location and physical properties of that magma is therefore important in determining the potential hazard of the magma reservoir, and its likelihood to erupt. Geophysical images of active, high silica magma systems, are usually obtained using InSAR, seismic, or magnetotelluric methods (e.g. Bachmann et al., 2007; Pritchard and Gregg, 2016, and references therein). Surprisingly, gravity images are less common, in spite of the strong density contrast produced by high silica magmas with their surrounding crust (e.g. Masturyono et al., 2001; DeNosaquo et al., 2009; del Potro et al., 2013; Saxby et al., 2016). Many rhyolitic calderas have substantial Bouguer gravity anomalies but these are often caused by caldera infill (Kane et al., 1976; Davy and Caldwell, 1998), rather than the underlying magmatic system.

In this study we present a new, 3D gravity inversion scheme using the opensource Simulation and Parameter Estimation in Geophysics (SimPEG) frame- 
work (Cockett et al., 2015) http://www.simpeg .xyz, and importantly, consider thermodynamic effects on the magma system density. Thermodynamic modelling using the free MELTS code (Gualda and Ghiorso, 2015) considers crystal, melt and volatile phases as well as pressure and temperature conditions when computing magma system densities. Consideration of the volatile phase is important for determining the total magma system density and thus for the correct interpretation of gravity inversion results, as volatiles control many processes which drive or hinder eruptions (Huppert et al., 1982; Sparks and Huppert, 1984; Wallace et al., 1995; Malfait et al., 2014).

Gravity models of volcanoes are not new, however the inversion codes are often poorly documented, proprietary, or expensive, making them difficult to be widely adopted or benchmarked. While there are popular free codes used in volcanology (e.g. Camacho et al., 2011), a growing number of open-source codes is developing in the broader geophysical community (e.g. Uieda et al., 2013; Cockett et al., 2015; Rucker et al., 2015). These codes are transparent, flexible, and maintained by a cohort of users that contribute bug fixes and improvements as desired. SimPEG is open-source and offers significant benefits, including; 1) a mixed $\mathrm{L}_{p}$ norm inversion on both model values, and the gradient of their distribution, to better simulate geologic models with sharp or gradational boundaries according to the user's preference, 2) the option to use a non-zero starting model to incorporate a priori knowledge, 3) the ability to include a reference model in the objective function that may help reconcile models from complimentary disciplines, 4) the option to designate cells as active or inactive in the inversion. The modular framework also allows inversion of other geophysical datasets. SimPEG is python based, meaning it is free and platform independent, allowing the user to have a seamless work-flow within the python environment, from data processing to inversion, visualisation and interpretation.

Gravity surveys are well suited for rapid reconnaissance of shallow magmatic systems as the data are quick to acquire, and inversion models are fast to run.

Using whole rock geochemistry data for input into MELTS, combined gravity and thermodynamic modelling provide insights into the present state of a mag- 
matic system and the hazard it presents. Importantly, the combined analysis may offer significantly different interpretations than if the gravity data are considered in isolation. We apply this method to image a shallow rhyolite magma reservoir beneath the Laguna del Maule volcanic field (LdMVF) and determine its key physical properties.

The LdMVF is located on the range crest of the southern Andes at $36^{\circ} \mathrm{S}$, bordering Chile and Argentina and is geographically characterised by a lake enlarged around $19 \mathrm{ka}$, following the damming of its outlet by the Espejos rhyolite lava flow (unit rle). The LdMVF comprises the largest concentration of high silica rhyolite in the Andes with at least 50 post-glacial eruptions since $25 \mathrm{ka}$; including four between 3.3 and $2.1 \mathrm{ka}$ (units rsl, rcd, $r l n$ and western rcb) (Andersen et al., 2016). These eruptions were from 24 vents and produced 15 rhyodacite, and 24 rhyolite lava flows and domes (Singer et al., 2014). The position of the eruptive units and post-glacial vents is shown in Figure 1. Previous large volume silicic eruptions include a dacite ignimbrite at $1.5 \mathrm{Ma}$ (igsp), and a rhyodacite tuff associated with the Bobadilla caldera at $0.95 \mathrm{Ma}$ (igcb) (Hildreth et al., 2010). The post-glacial decrease in mafic eruption frequency, and their spatially peripheral location, is inferred as evidence for a large, low density, high silica magma system acting as a density barrier for ascent of mafic magma.

Since 2007, the LdMVF has experienced uplift at rates over $20 \mathrm{~cm} /$ year (Le Mével et al., 2015), which Feigl et al. (2014) and Le Mével et al. (2016) interpret as resulting from inflation of a sill at around $5 \mathrm{~km}$ depth beneath the lake caused by the addition of new magma into the reservoir. By defining the location of the present day magmatic system and its physical properties, we provide the context to accurately interpret and understand the ongoing unrest and create a framework for interpreting monitoring data. From our model we estimate the melt vs crystal proportions and their distribution, the degree of pressurisation of the system, and investigate the implications of ratios of magma intruded to erupted. We consider the location of the magma system in relationship to the eruptive vents, the local tectonic framework and the ongoing deformation, and 
throughout we consider the hazard implications of our model.

\section{Gravity data collection and reduction}

In 2014, 2015, and 2016, we collected 239 terrestrial gravity measurements within a $10 \mathrm{~km}$ radius of the lake shore (Figure 1). We took measurements every $500 \mathrm{~m}$ around the accessible shoreline, on islands, and in a series of radial profiles extending 3 - $4 \mathrm{~km}$ from the lake. Thirty measurements were collected farther from the lake to define the regional gravity field. For precise positioning we used a Leica 530 GPS receiver with 15 minute occupation time per station; with maximum baseline lengths of $10 \mathrm{~km}$ to the Observatorio Volcanologico de Los Andes del Sur (OVDAS) CGPS network, we obtain height errors of better than $15 \mathrm{~cm}(\sim 0.045 \mathrm{mGal})$ at $95 \%$ confidence level. We correct the daily raw gravity data for Earth tide and drift using Gtools (Battaglia et al., 2012), to produce gravity values relative to our local base. We convert our local gravity values to absolute values using two nearby absolute gravity stations (S. Bonvalot pers comm) to a measured accuracy of $0.016 \mathrm{mGal}$.

We correct the gravity data to the ellipsoid height datum as our heights are derived from GNSS measurements referenced to the WGS84 ellipsoid and follow the data reduction scheme outlined in Hinze et al. (2005). See supplementary materials for details. The DEM used for terrain corrections does not take into account the bathymetry of the lake, resulting in the terrain corrections for stations near the lake being over estimated, due to low density water being corrected as dense rock. To determine the gravity effect of the lake we construct a forward model of the bathymetry using data acquired by Carrevedo et al. (2015). We use an implementation of Talwani's algorithm (Talwani and Ewing, 1960), to compute the gravity effect of the lake water (density $=1000$ $\left.\mathrm{kg} / \mathrm{m}^{3}\right)$ at each gravity station. The lake correction at each station $i,\left(\mathrm{~g}_{i_{L C}}\right)$, which is subtracted from the terrain correction, is given by:

$$
g_{i_{L C}}=\left(\frac{\rho_{T C}}{\rho_{W}}\right) g_{i_{\text {lake }}}
$$


where $\rho_{T C}$ is the terrain correction density, $\rho_{W}$ is the water density and $g_{i_{\text {lake }}}$ is the calculated gravity effect of the lake at each station. A maximum lake correction of $0.32 \mathrm{mGal}$ is calculated at a station on one of the islands.

We use a combination of methods to determine the best Bouguer and terrain correction density with a summary presented in Figure 2 and details in supplementary material. Analysis of our gravity data and topography, using Nettleton (1939) and Parasnis (1966) methods, give densities of $2375 \mathrm{~kg} / \mathrm{m}^{3}$ and $2361 \pm 61 \mathrm{~kg} / \mathrm{m}^{3}$, respectively. The same analysis on a nearby commercial dataset (Energy Development Corporation) gives values of 2450 and $2452 \pm$ $24 \mathrm{~kg} / \mathrm{m}^{3}$. Additionally, we convert the OVDAS 1D seismic velocity model to density using the relationship of Brocher (2005). The top $3 \mathrm{~km}$ of this model gives densities of $2429 \mathrm{~kg} / \mathrm{m}^{3}$, increasing to $2448 \mathrm{~kg} / \mathrm{m}^{3}$ at $7 \mathrm{~km}$ depth. The average of all the density determinations is $2413 \pm 42 \mathrm{~kg} / \mathrm{m}^{3}$ which we round to $2400 \mathrm{~kg} / \mathrm{m}^{3}$ for use in the gravity reduction. We estimate an RMS error on the Bouguer anomaly of $0.11 \mathrm{mGal}$.

\section{Gravity anomaly}

A striking gravity low embedded within an east-west trending gradient is the dominant feature of the Bouguer anomaly map (Figure 3A). The heterogeneous data coverage, results in the gravity anomaly over the lake being interpolated between sparse data points. While this is unavoidable, we highlight that the true shape and amplitude of the anomaly may vary slightly from that presented. Areas shaded in grey are those areas of the main anomaly where the nearest gravity station is more than $1 \mathrm{~km}$ away. To isolate the anomaly, we remove a third order polynomial to approximate the regional field, resulting in a residual gravity anomaly (Figure 3B). The third order polynomial was chosen as the lowest order polynomial surface that suitably replicates the regional data. The regional field is oriented parallel to the South American / Nazca tectonic plate boundary and reflects the eastward dipping subducting plate. The residual gravity anomaly shows a $-19 \mathrm{mGal}$, rectangular shaped gravity low, oriented 
NNE and centred on the south shore of the lake, coincident with the centre of inflation modelled by Feigl et al. (2014). The gravity low is contained within the ring of post-glacial rhyolite vents that encircle the lake. Localised gravity highs up to $9 \mathrm{mGal}$, occur to the east of the lake.

Using Gauss's theorem, where:

$$
\Delta M=\frac{1}{2 \pi G} \iint \Delta g(x, y) d x d y
$$

we calculate the mass deficiency, $\Delta \mathrm{M}$, required to produce the main gravity anomaly, $\Delta \mathrm{g}$, of $1.1 \times 10^{13} \mathrm{~kg}$, where $\mathrm{G}$ is the gravitational constant, contained within an area $(x, y)$ of $95 \mathrm{~km}^{2}$. This mass is independent of the geometry of the body within which it is contained.

\section{Inversion and interpretation}

To determine the density distribution within the subsurface, we undertake a 3D inversion using a Gauss-Newton, gradient based approach, implemented in the open source SimPEG framework (Cockett et al., 2015). SimPEG is particularly well suited for volcano surveys where inaccessible topography results in irregular data coverage, as a regular grid of data is not required. We implement a novel $\mathrm{L}_{p}$ norm, 'compact' inversion scheme, with a summary described below and further details, including a link to the inversion code, in the supplementary materials.

We construct a 3D mesh with $250 \times 250 \mathrm{~m}$ horizontal cell size, with vertical cell size increasing by a factor of 1.2 from $100 \mathrm{~m}$ in the top $500 \mathrm{~m}$, to $350 \mathrm{~m}$ at the base of the grid at $-5000 \mathrm{~m}$ a.s.l., resulting in 190,440 cells. The mesh covers a subset of the Bouguer gravity anomaly where the station density is highest, using 192 of the 239 stations (rectangular box in Figure 3B). Note that there is no interpolation of data in the inversion routine, only the measured gravity data are used.

The two main elements of the inverse problem are the data misfit, and the regularisation scheme. Data misfit is a metric which measures the difference be- 
tween observed and predicted data, while regularisation is a metric that is constructed to evaluate the model's agreement with assumptions and prior knowledge. We define the data misfit of the model $\phi_{d}(\mathbf{m})$ as:

$$
\phi_{d}(\mathbf{m})=\frac{1}{2}\left\|\mathbf{W}_{d}\left(F[m]-\mathbf{d}_{o b s}\right)\right\|_{2}^{2}
$$

Where $\mathbf{d}_{o b s}$ is the observed data, $F[m]$ is a forward model that produces predicted data, and $\mathbf{W}_{d}$ is a diagonal matrix with elements equal to $\mathbf{W}_{d_{i i}}=$ $1 / \epsilon_{i}$ where $\epsilon_{i}$ is the standard deviation of the $i$ th data point. We set $\epsilon$ to 0.1 mGal for our model.

The second element is the regularisation function. Infinitely many models can fit the dataset, so we wish to find the model that has the desired characteristics, and is compatible with a priori information. A single model can be selected from the infinite set of models by measuring the length, or norm of each model. In our workflow, we run a two step inversion process, firstly inverting the data with a 'smooth' constraint imposed with a $\mathrm{L}_{2}$ norm. Secondly, we compact the smooth model using a $\mathrm{L}_{p}$ norm, where $0 \leqslant p \leqslant 2 . \mathrm{L}_{2}$ norm models tend to create bodies with poorly defined, 'smeared out' boundaries (Sun and Li, 2014), however our geologic conceptions of a magma reservoir as a finite body with defined edges (e.g. Bachmann and Bergantz, 2008; Cashman and Giordano, 2014, and examples therein), are better represented mathematically by a $\mathrm{L}_{p}$ norm that produces a more compact body with sharper edges.

To produce a compact model, we inspect the distribution of model values and gradients of the $\mathrm{L}_{2}$ norm model, $\epsilon_{p}$ and $\epsilon_{q}$, to find suitable values (See supplementary material Figure 2). The choice of $\epsilon_{p}$ and $\epsilon_{q}$ is arbitrary, depending on the level of compactness required, and we choose the $95^{\text {th }}$ percentile of the $\mathrm{L}_{2}$ model distribution after visual inspection of models with a range of values. The effect of $\epsilon_{p}$ and $\epsilon_{q}$ is to flatten the model value and gradient histograms towards having more values equal to $\epsilon_{p}$ and $\epsilon_{q}$, such that the model becomes less smooth, and more compact.

We solve the inverse problems using a scaled iterative re-weighted least 
squares optimisation approach and define a composite objective function as:

$$
\phi(\mathbf{m})=\phi_{d}(\mathbf{m})+\beta \phi_{m}(\mathbf{m})
$$

where $\beta$ is the tradeoff or Tikhonov parameter. A small $\beta$ results in a model that fits the data very well, but may include excessive structure so that $\phi_{m}(\mathbf{m})$ is large. Conversely if $\beta$ is large, the optimisation results in a large $\phi_{d}(\mathbf{m})$. To select the optimal $\beta$, we use an L-curve approach and stop adjusting $\beta$ when we have reached the target misfit. The optimisation is nonlinear so a gradientbased, Gauss-Newton method is used.

To run the inversion, we search for a perturbation of the model that reduces the objective function. The iterative optimisation process continues until the algorithm converges to a minimum and the misfit tolerance is achieved.

\subsection{Model resolution}

We investigate how the lack of gravity stations over the lake might affect the accuracy of the inversions by creating a checkerboard test, similar to that used in seismic tomography (Humphreys and Clayton, 1988). We create a density model consisting of square prisms $(3.5 \mathrm{~km}$ horizontal sides) of alternating density, +300 and $-300 \mathrm{~kg} / \mathrm{m}^{3}$. The width of the prisms is chosen to reflect the width of the gravity anomaly at half its amplitude and also corresponds to the east-west distance across the lake, through the center of the anomaly, where there are no gravity stations. The elevation of the top of the prisms is $1000 \mathrm{~m}$ a.s.l., and they are $1 \mathrm{~km}$ thick, except for the centre prism which is $2 \mathrm{~km}$ thick. The depth to the top of the prisms from topographic surface, ranges from $\sim 1200 \mathrm{~m}$ to $1500 \mathrm{~m}$. In this model, we test the sensitivity of the dataset to the lateral, top and bottom boundaries of bodies of similar dimensions to the residual gravity anomaly as well as the resolved densities. We calculate the gravity effect of the checkerboard at each station, and use this as input data into the inversion routine.

The results of the checkerboard (Figure 4) show that the outlines of all the prisms are resolved even for prisms with few data points. Prisms bordering 
the lake shore, where there are many stations closer to the top of the prisms, are better resolved, both laterally and at depth, compared to the outer prisms with fewer stations at greater depths. Prisms with fewer stations are generally recovered shallower, and with less density contrast than the true model. As such, we have confidence that for the size of the observed anomaly, the coverage of our stations should accurately determine the lateral extent of the anomalous body, especially in an east-west direction. Lateral boundaries across the lake in the north-south direction may be less well resolved and the density may be under estimated in areas of poor station coverage. The $500 \mathrm{~m}$ station spacing places an additional resolution limit on the smallest resolvable feature, in areas of good station coverage, of approximately $1 \mathrm{~km}$.

\subsection{Inversion constraints from thermodynamic models}

The data collected in any geophysical survey are finite in number, while the physical property distribution in the Earth is continuous, resulting in an ill posed problem with no unique solution. To constrain the inversion, and reduce the number of possible models, we investigate the likely range of densities of magma found at LdMVF. As the observed gravity anomaly is an integral of all magmatic phases, (solids, liquids and exsolved gases), we must include the effect of $\mathrm{H}_{2} \mathrm{O}$ and $\mathrm{CO}_{2}$ and their behaviours in the system at different temperature and pressure conditions, when calculating magma system densities. While there is no open vent degassing or surface fumaroles at the LdMVF, we have measured $\mathrm{CO}_{2}$ soil gas concentrations of up to $5 \%$ by volume in places around the lake shore, and in our modelling we test the sensitivity of the melt density to varying $\mathrm{CO}_{2}$ concentrations as described below. For the volumetrically dominant $\mathrm{H}_{2} \mathrm{O}$ vapour phase we assume a closed system where that phase is retained. We use rhyolite MELTS for Excel (Gualda and Ghiorso, 2015) to calculate total magma system densities at equilibrium conditions from whole rock analyses representative of the most recently erupted rhyolites $(r s l, r c d, r l n)$, over a range of temperature and pressure conditions, representing various proportions of vapour, liquid and solid magma. We note that evolution and degassing of rhyolite magma may not 
always strictly occur at equilibrium conditions (e.g. Gonnermann and Manga, 2005) so that the melt may be more or less saturated in volatiles than our calculations suggest. As such, the calculated densities of the magma system at equilibrium should be considered as minimum values.

The rhyolites contain a narrowly varying range of $\mathrm{SiO}_{2}$, between 73.5 to 75 wt \% (Andersen et al., 2016), and we use an average composition for our analysis. We also compute densities from rhyodacites $r d c n$ and $r d c d$ (average 69.4 wt $\% \mathrm{SiO}_{2}$ ), and andesites asd and $m c p$ (63 and 53 wt $\% \mathrm{SiO}_{2}$ respectively) to test our model sensitivity to different compositions, as the magma reservoir is unlikely to be solely rhyolite (see Supplementary Figure 3). Common biotite, sparse amphibole and very rare pyroxene in the silicic units indicates high water content, so we used 5 wt $\% \mathrm{H}_{2} \mathrm{O}$, derived from plagioclase-glass hygrometry (range 4.75-7.25 wt \%, N. Andersen pers comm July 2016), and in the absence of melt inclusion information, fixed $\mathrm{CO}_{2}$ at $100 \mathrm{ppm}$, typical of arc-rhyolites (Gonnermann and Manga, 2012). As a sensitivity test, we calculate rhyolite densities using water contents of 3,4 and 5 wt $\%$ and found that a minimum of 4 wt $\% \mathrm{H}_{2} \mathrm{O}$ is required to reproduce the observed gravity (Supplementary Figure 4). The effect of increasing water content is to decrease the total density of the system for any given pressure or temperature. At the low pressures present at the depth of our gravity model, $\mathrm{CO}_{2}$ is already exsolved so varying its concentration several fold makes only negligible density difference and we do not consider further the role of $\mathrm{CO}_{2}$.

Calculated rhyolite magma system densities (Figure 5) vary from 1300 to $2100 \mathrm{~kg} / \mathrm{m}^{3}$, over the pressure range of 50 to $120 \mathrm{MPa}(\sim 2$ to $5 \mathrm{~km}$ depth for a crustal density of $2400 \mathrm{~kg} / \mathrm{m}^{3}$ ), and temperature range of 700 to $920{ }^{\circ} \mathrm{C}$ (approximate solidus to above liquidus), giving a range of density contrasts from the gravity reduction density of -1100 to $-300 \mathrm{~kg} / \mathrm{m}^{3}$. Feigl et al. (2014) model a sill at $\sim 5 \mathrm{~km}$ depth (120 MPa), which we use as a constraint for the upper end of the likely pressure range. The rhyodacite density varies from the rhyolite density by a maximum of only $80 \mathrm{~kg} / \mathrm{m}^{3}$ making the distinction between the two compositions not explicitly resolvable in our model. Andesite densities at 1020 
${ }^{\circ} \mathrm{C}$ geothermometer temperatures (Andersen et al., 2016) with 3 wt $\% \mathrm{H}_{2} \mathrm{O}$ at $90 \mathrm{MPa}$, are 2200 to $2300 \mathrm{~kg} / \mathrm{m}^{3}$, a contrast of -200 to $-100 \mathrm{~kg} / \mathrm{m}^{3}$.

Figure $5 \mathrm{~A}$ is annotated with isolines of the percentage rhyolite melt in the system at each pressure modelled. The green shaded area represents the temperature range of the Holocene rhyolite and rhyodacite magmas prior to eruption $\left(\sim 790\right.$ to $\left.854^{\circ} \mathrm{C}\right)$, calculated from the Fe-Ti geothermometer and provide further constraints on the range of probable densities.

The shape of the temperature vs density curves reflects the importance of including the full thermodynamic, crystallisation and volatile phase effects in the density calculations, not simply calculating the density of the liquid phase (Figure 6). Below the liquidus, the system density decreases, reflecting the start of feldspar crystallisation, exsolving $\mathrm{H}_{2} \mathrm{O}$ from the melt. When quartz and $\mathrm{K}$ feldspar start to crystallise, more $\mathrm{H}_{2} \mathrm{O}$ is exsolved further lowering the total density of the magma system. However, at LdMVF quartz $+\mathrm{K}$ feldspar crystallisation is not observed in the rhyolite mineralogy, implying the temperature of the system remains above this point (green box in Figure 6). The high temperatures also limit the amount of exsolved $\mathrm{H}_{2} \mathrm{O}$ to around 2.5 wt \%. The implication of these dynamics and the importance of modelling the vapour phase, with respect to the interpretation of gravity data at active magmatic systems, is explored further in the Discussion section 5.1.

To utilise these constraints, we run a suite of inversions where the lower density contrast bound is increased from -1100 to $-200 \mathrm{~kg} / \mathrm{m}^{3}$ in steps of 100 $\mathrm{kg} / \mathrm{m}^{3}$. The upper bound is fixed at $300 \mathrm{~kg} / \mathrm{m}^{3}$ to account for the positive gravity anomalies, assuming that the densities of intermediate and silicic volcanic rocks are unlikely to be more than $2700 \mathrm{~kg} / \mathrm{m}^{3}$.

\subsection{Inversion results}

First, we consider which of the suite of geophysically feasible models is most viable from a geological perspective. The models that are valid over the greatest ranges of pressure conditions are from -600 to $-400 \mathrm{~kg} / \mathrm{m}^{3}$ (Figure 5). For example, the $-600 \mathrm{~kg} / \mathrm{m}^{3}$ model is valid from 80 to $100 \mathrm{MPa}$, or 3 to $4.2 \mathrm{~km}$ 
depth, while the $-400 \mathrm{~kg} / \mathrm{m}^{3}$ model is valid from 100 to $120 \mathrm{MPa}$, or 4.2 to 5.1 $\mathrm{km}$ depth. The central body of the -500 and $-600 \mathrm{~kg} / \mathrm{m}^{3}$ density contrast models have very similar volume $\left(\sim 30 \mathrm{~km}^{3}\right)$, indicating that at these values the model is less sensitive to changes in density and these are our preferred models. While the more extreme density contrast models, -900 to $-1100 \mathrm{~kg} / \mathrm{m}^{3}$, are geophysically feasible, they are unable to represent the bulk of the magma reservoir when thermodynamic data are considered as they are valid only for very low pressures and result in low melt proportion magmas $(<50 \%)$ inconsistent with geologic observations of crystal poor lava. In the lowest density contrast models (-200 and $-300 \mathrm{~kg} / \mathrm{m}^{3}$ ), a poorly defined low density body extends to the base of the model volume. There is no difference between the $\mathrm{L}_{p}$ norm and $\mathrm{L}_{2}$ norm models, indicating that at these density contrasts, there is insufficient mass available to reproduce the gravity anomaly. These two models are not considered geologically reasonable, and are not discussed further.

The preferred inversion model of +300 to $-600 \mathrm{~kg} / \mathrm{m}^{3}$ (Figure 7 ) converges with an RMS of $0.032 \mathrm{mGal}$, in 175 seconds on an Intel i7, $2.7 \mathrm{GHz}$ processor with $16 \mathrm{~Gb}$ ram. The distribution of observed - calculated values are normally distributed around zero and show no obvious geographic bias (see Supplementary Figure 5). The shallowest layers of this model show a ring of higher density material broadly coincident with vent locations to the west and south of the lake, while in the north, the Espejos vent, lava flow (rle) and pumice deposit is coincident with lower density material. The high - low - high density pattern across the north shore of the lake is present in all depth slices. The western boundary of this feature is broadly coincident with the inferred boundary of the Bobadilla caldera (Hildreth et al., 2010). The inferred caldera boundary is $1-2 \mathrm{~km}$ to the west of the gravity boundary, however its location is poorly constrained as it is buried by more recent volcanism.

Depth slices at 1500 and $1100 \mathrm{~m}$ a.s.l. show an irregular shaped low density region (contrast $-200 \mathrm{~kg} / \mathrm{m}^{3}$, outlined with a dashed blue line in Figure 7 ), covering most of the lake and shoreline, and extending to the north under the Espejos rhyolite lava flow (rle) and pumice deposits. This is similar to the 
extent of the shallow conductor mapped with magnetotellurics by Cordell et al. (2015). At $0 \mathrm{~m}$ a.s.l. a low density body (contrast $-600 \mathrm{~kg} / \mathrm{m}^{3}$ ), appears in the central portion of the lake. At $-1100 \mathrm{~m}$ a.s.l. (approx $3 \mathrm{~km}$ depth), the main features of the model are a central low density body and a finger of lesser density contrast material to the north. The central low density body sits within a 1-2 $\mathrm{km}$ wide ring of lower density contrast material, shown as the dashed red line in slice $-2150 \mathrm{~m}$, which is broadly coincident with the location of a sill modelled by Feigl et al. (2014) to explain present day deformation.

The main feature of our gravity model is a central low density body of uniform density throughout its thickness. Gravity is inherently poor at resolving horizontal layering that a magma system may exhibit, so our density model reflects the average bulk density of the system. The possible composition of this body is outlined in the Discussion, section 5.1. The volume of the central body at each model density contrast is shown in Figure 8 along with the proportion of melt possible at each density contrast and pressure range. Volumes of the anomalous body range from 6 to $50 \mathrm{~km}^{3}$ for density contrasts of -1100 to $400 \mathrm{~kg} / \mathrm{m}^{3}$, respectively. The overall effect of different density contrast models is to swell or shrink the central body, whilst retaining its same general shape (Supplementary Figure 6).

At $-500 \mathrm{~kg} / \mathrm{m}^{3}$, the base of the body is around $-4000 \mathrm{~m}$ a.s.l. At $-600 \mathrm{~kg} / \mathrm{m}^{3}$, the central body shrinks with a lower surface at around $-3500 \mathrm{~m}$ a.s.l., while at $-700 \mathrm{~kg} / \mathrm{m}^{3}$ and higher contrasts, the base of the body stabilises at around -3000 m a.s.l. Thus, the thickness of the central body varies between 3 and 4 $\mathrm{km}$ over a $200 \mathrm{~kg} / \mathrm{m}^{3}$ density range. A 3 dimensional representation is shown in Figure 9 for the $-600 \mathrm{~kg} / \mathrm{m}^{3}$ density contrast model and shows a $30 \mathrm{~km}^{3}$ body hosted within a $115 \mathrm{~km}^{3}$ body of less density contrast.

\subsection{Alternate scenario}

We investigate an alternate scenario of a thick, low density surface layer to explain the residual Bouguer anomaly. Preliminary results from MT surveys (Cordell et al., 2015) indicate a low resistivity layer extending from near surface 
to several hundred metres depth and interpreted as hydrothermal alteration or conductive lake sediments. This conductive layer covers much of the lake basin, with a footprint wider than the extent of the main Bouguer anomaly. Hydrothermal alteration often results in low density (e.g. Miller and WilliamsJones, 2016) from the chemical alteration of rock to low density clays. Recent field mapping, (J. Fierstein, pers comm $19^{\text {th }}$ May 2016), identified a probable vent area under the lake, from an ignimbrite deposit mapped to the east, which is likely to have produced a thick accumulation of low density pyroclastic material within the lake basin. To test this scenario, we create a $500 \mathrm{~m}$ thick layer extending from the surface, with a density contrast of $-300 \mathrm{~kg} / \mathrm{m}^{3}$. The extent of the surface layer is the dashed blue outline in Figure 7, slice 0 and $1500 \mathrm{~m}$ a.s.l.. The cells inside the surface layer were fixed in the inversion, with the remaining model cells allowed to vary, so that the effect of the layer is included in the inversion but it is not adjusted. The ability to fix cells demonstrates the flexibility of SimPEG and allows us to easily explore alternate scenarios through a mix of forward and inverse modelling. The inversion result (Supplementary Figure 7) still requires considerable material beneath the surface layer to replicate the magnitude of the observed anomaly, and we conclude that the Bouguer anomaly cannot be solely caused by shallow low density material.

\section{Discussion}

We use our preferred density model of the LdMVF to consider questions related to the current state of the magma system, its relationship to eruptive vents and present day deformation and the potential for future eruptions.

\subsection{How much melt is present, and of what composition?}

The percentage of melt in a magma reservoir is a key determinant in that system's ability to erupt. By using a thermodynamic modelling approach, rather than simply calculating melt densities, we are able to extract proportions of melt, crystal and volatiles from our model. At crystal fractions greater than 
50 to $60 \%$, a mechanical threshold is reached where crystals start to interlock, eventually forming a rigid sponge, inhibiting the flow of magma and reducing its ability to erupt (Marsh, 1981; Bachmann and Bergantz, 2008). However, the range of 50 - $60 \%$ crystals is also where melt extraction from the crystal mush is most efficient, promoting the growth of eruptible, crystal poor caps to magma reservoirs (Bachmann and Bergantz, 2004; Charlier et al., 2005).

Figures 5 and 8 show that for a given density contrast, a range of scenarios is possible, suggesting a crystallinity zoned reservoir. For example at $-500 \mathrm{~kg} / \mathrm{m}^{3}$, sub-liquidus magma exists at 90, 100 and $110 \mathrm{MPa}(\sim 3.8$ to $4.7 \mathrm{~km}$ depth). At $90 \mathrm{MPa}, 85 \%$ melt is possible, at $100 \mathrm{MPa}, 60 \%$ melt is possible, while at 110 MPa, scenarios of 4 or $35 \%$ melt are possible, depending on the temperature.

Compositional gradients and the spatial distribution of crystals and melt within the reservoir are not explicitly resolvable within our model as gravity methods are relatively insensitive to horizontal layering. So, although we have assumed a uniform composition of the magma comprising the reservoir, the crystallinity gradient inferred is likely partially driven by variations in composition. Including more mafic material at depth will allow for higher crystallinities at higher temperature, without saturating in sanidine at the granite minimum (Andersen et al., 2016). These thermodynamic requirements are backed by field evidence of mafic and intermediate enclaves in post-glacial rhyodacite lavas (Hildreth et al., 2010) and by the model of Le Mével et al. (2016) for the injection of basalt into the base of the reservoir.

The calculated densities of andesite produce only a small density contrast $\left(-100\right.$ to $\left.-200 \mathrm{~kg} / \mathrm{m}^{3}\right)$ with the background density (Supplementary Figure 3B). For the entire active reservoir to be made of this composition requires a volume 3 to 6 times greater than what is modelled to reproduce the observed gravity anomaly and such a volume is not feasible. The density contrast of andesite magma is close to that ascribed to the larger rim surrounding the active reservoir (red dashed line Figure 7), and it is possible that this rim is of intermediate composition and high crystal proportion $(\sim 70 \%$ crystals at the modelled density contrast). A composite magma system of andesite and rhyolite magma 
would have an overall density contrast of $-400 \mathrm{~kg} / \mathrm{m}^{3}\left(-600 \mathrm{~kg} / \mathrm{m}^{3}\right.$ rhyolite and $-200 \mathrm{~kg} / \mathrm{m}^{3}$ andesite) which our gravity models show requires a volume of 50 $\mathrm{km}^{3}$. However, to reproduce the observed gravity (ignoring geometry), a 3:1 ratio of andesite to rhyolite is required to account for the lower density contrast of andesite compared to rhyolite magma. A $50 \mathrm{~km}^{3}$ reservoir would require $\sim 38$ $\mathrm{km}^{3}$ andesite and $12 \mathrm{~km}^{3}$ rhyolite. This simplistic analysis ignores the effects of geometry, where the andesite is likely at greater depth than the rhyolite, resulting in a lower contribution of andesite magma to the observed gravity. In order to quantify the proportions of different magma types, an independent estimate of the reservoir volume is required.

The rhyolite melt proportions are calculated using 5 wt $\% \mathrm{H}_{2} \mathrm{O}$, which is at the lower end of the range of measured values (N. Andersen, pers comm July 2016). The effect of increasing water content is to increase the melt proportion for any given density contrast. For example, at 6 wt $\% \mathrm{H}_{2} \mathrm{O}$ at $90 \mathrm{MPa}, \sim 95$ $\%$ melt is calculated at a density contrast of $-600 \mathrm{~kg} / \mathrm{m}^{3}$, compared to $\sim 60 \%$ melt at 5 wt $\% \mathrm{H}_{2} \mathrm{O}$. Therefore melt proportions may be considered minimums.

We can further constrain the likely range of melt proportion, by considering the temperature of the magma system. Using the Fe-Ti oxide geothermometer, Andersen et al. (2016) calculated pre-eruptive magmatic temperatures of between $\sim 790$ to $854{ }^{\circ} \mathrm{C}$ for the Holocene rhyolites and rhyodacites. Models with density contrasts within this temperature range are shown by a star symbol in Figure 8. This temperature range intersects our preferred -500 and -600 $\mathrm{kg} / \mathrm{m}^{3}$ density contrast models at melt fractions of 50 to $85 \%$ (shown by larger star symbols). As the temperatures are derived from erupted lavas, the $85 \%$ melt fraction is likely to represent the shallowest portion of the magma reservoir and is consistent with field observations that the rhyolitic lavas and tephras are crystal-poor (Singer et al., 2014; Hildreth et al., 2010).

A credible configuration of the present day LdMVF magma system from density contrast, temperature and melt percentage data is a crystallinity zoned magma reservoir with a shallow, crystal poor rhyolite magma (>85\% melt), e.g. 'holding zone' of Charlier et al. (2005), overlying progressively more crystal rich 
magma $(<50 \%$ melt). This reservoir is surrounded by a cumulate mush e.g. 'root zone' of Charlier et al. (2005), of intermediate composition and densities close to the host rock. A density zoned magma reservoir is consistent with a hypothesis that each of the LdMVF eruptions tapped only the top of the magma system. As melt proportion falls below $50 \%$, it becomes more difficult to erupt, favouring the eruption of only the shallowest, crystal poor part of the system. The $50 \%$ melt fraction is also within the zone of most efficient extraction of melt from crystal mush, so the magma reservoir may be in a suitable configuration to repeatedly generate a cap of low crystal content, eruptible rhyolite overlying a crystal rich mush. Importantly for hazard considerations, Castro and Dingwell (2009), from the 2008 Chaiten eruption, and Castro et al. (2013) and, Jay et al. (2014), from the 2011-12 Cordon Caulle eruption, showed that, near liquidus, volatile rich rhyolite magma, such as is present at LdMVF, is very fluid and can migrate rapidly from source to eruption site, resulting in very little warning prior to eruption.

\subsection{Is the LdMVF magma system over-pressured?}

We investigate whether the large density contrast of the imaged shallow magma reservoir with the surrounding crust is enough to generate magma overpressure that exceeds lithostatic pressure. Gregg et al. (2015) provide a simple 1-D formulation for calculating the over pressure from a density contrast, taking into account the restoring force imposed by the lithostatic load $\left(P_{\text {litho }}\right)$ on the magma pressure head $\left(\Delta P_{\text {buoy }}\right)$. The overpressure OP is defined as:

$$
O P=\Delta P_{\text {buoy }}+P_{\text {litho }}
$$

or

$$
O P=\Delta \rho g h_{c h}-\rho_{r} g z
$$

where $\Delta \rho$ is the density contrast between magma, $\rho_{m}$, and host rock, $\rho_{r}, \mathrm{~g}$ is acceleration due to gravity $\left(9.8 \mathrm{~m} / \mathrm{s}^{2}\right), \mathrm{h}_{c h}$ is the height of the magma reservoir and $z$ is the depth to top of the reservoir. 
The assumptions of this formulation are of a spherical magma reservoir at a depth greater than the reservoir radius. The reservoir imaged at LdMVF approximates these conditions, as the geometry aspect ratio is $\sim 2: 1$ and radius $\approx$ depth.

For the $\sim 3 \mathrm{~km}$ thick magma reservoir imaged at LdMVF, at $2 \mathrm{~km}$ depth, with a maximum magma/host rock density contrast of $-1100 \mathrm{~kg} / \mathrm{m}^{3}, \Delta P_{\text {buoy }}=$ $32.3 \mathrm{MPa}$ and $P_{\text {litho }}=47.0 \mathrm{MPa}$, resulting in an overpressure of $-14.7 \mathrm{MPa}$. The lithostatic load is around $50 \%$ more than the magma pressure head and no resultant buoyancy force exists, and is likely to require external triggering to generate an eruption (e.g. Allan et al., 2012). The preferred -500 to -600 $\mathrm{kg} / \mathrm{m}^{3}$ density contrast models, more representative of the whole reservoir, result in even lower head pressures. However, if the system is decompressed, the significant volatile phase is likely to result in a hazardous explosive eruption.

We note that if we only consider the melt phase density (refer to Figure 6), then our estimates of buoyancy would be substantially incorrect as the melt only phase density is much closer to the host rock density, resulting in a much reduced buoyancy force value. Additionally, melt only density models will not consider the exsolution of a free vapour phase, which may lead to an incorrect assessment of the hazard potential and likelihood of an explosive gas driven eruption.

\subsection{Magma reservoir volume vs erupted volume}

The volume of magma erupted is often used as a proxy for the volume of magma intruded into a system, to gain insights into the overall size of the magmatic system and what proportion of the total system is eruptible at any given time. There are relatively few studies where both the intruded and extruded volumes are accurately known (White et al., 2006), usually because the intruded volumes are poorly defined either by lack of outcrop or from low resolution geophysical imaging. There are two parts of the LdMVF magmatic system whose volumes we can compare to erupted volumes. A broad cumulate mush (115 $\left.\mathrm{km}^{3}\right)$ within which a smaller volume $\left(30 \mathrm{~km}^{3}\right)$ of active magma exists, from 
which an even smaller volume $\left(<2 \mathrm{~km}^{3}\right)$ of magma is periodically erupted.

The volume of post-glacial lavas at LdMVF is estimated at about $7 \mathrm{~km}^{3}$ with $30-40 \mathrm{~km}^{3}$ of pyroclastic material (Hildreth et al., 2010, J. Fierstein, pers comm 19th May 2016), for a total minimum volume of at least $40 \mathrm{~km}^{3}$. Comparing our modelled magma reservoir volume (including the cumulate mush margin, $115 \mathrm{~km}^{3}$ ) to the total post-glacial erupted volume, we calculate an intruded:extruded (I:E) ratio of 2.9:1, similar to that found at large silicic systems such as Yellowstone (3:1) (White et al., 2006).

When comparing the ratios of only the $r l n$ eruptives (the largest of the 3 most recent rhyolites, $\sim 2 \mathrm{~km}^{3}$ rhyolite lava and tephra), to our active magma reservoir volume (excluding the margin), using our preferred models with density contrasts of -600 and $-500 \mathrm{~kg} / \mathrm{m}^{3}$, we find an I:E ratio of $15: 1$. If the volume of the present day magma system has remained approximately constant since the last eruption at $\sim 2-3$ ka (ongoing intrusions account for relatively minor volumetric change), then a 15:1 I:E ratio suggests that the $r l n$ eruption tapped $\sim 7 \%$ of the reservoir.

Andersen et al. (2016) propose that chemical and temporal trends of erupted LdMVF rhyolites implies the extraction of chemically distinct melts from a long-lived, compositionally evolving upper crust reservoir. Our I:E ratios are consistent with such a reservoir, and as we discuss in section 5.4 the location of this eruptible magma may be required to migrate within the larger system to feed the mapped eruption vents.

The inflating sill modelled by Feigl et al. (2014), and the injection model of Le Mével et al. (2016) proposed to explain the current deformation event likely represent the intrusions required to sustain the reservoir, and imply that episodes similar to the present day intrusion and associated deformation have probably occurred many times. Indeed, the $>60 \mathrm{~m}$ of uplift and tilting of the high-stand paleoshoreline since $9.5 \mathrm{ka}$, suggests the current intrusion is not unique in the history of the LdMVF.

The LdMVF scenario, where small magma volumes are erupted from a long lived system, is similar to the small volume $\left(<1 \mathrm{~km}^{3}\right)$ post caldera forming 
eruptions at Long Valley. Reid et al. (1997) from analysis of Zr crystals from the 115 ka Deer Mountain rhyolite, found that frequent injections of mafic magma were required to maintain the magma system at high temperatures for long periods of time. A consequence of this is that the Long Valley magma reservoir remained molten for longer, resulting in the accumulation of a much larger volume of magma than that erupted.

In contrast, Taupo volcano is characterised by frequent eruption of compositionally distinct magma batches, held in ephemeral chambers little bigger than the erupted volume (Sutton et al., 2000), implying I:E ratios closer to unity. As an example, Wilson (1993) proposed that the eruption of unit S from Taupo evacuated the majority of the chamber, and that this was representative of the 28 other eruptions from Taupo since the $26.5 \mathrm{ka}, 530 \mathrm{~km}^{3}$ dense rock equivalent, Oruanui eruption. Additionally, Sutton et al. (2000) categorised Taupo eruptions into three subgroups and with no overlap in composition or time, suggesting the complete emptying of the reservoir between subgroups. The ability of Taupo eruption to effectively drain a large proportion of the chamber, and rapidly regenerate it, is proposed by Wilson and Charlier (2009) to be related to the active rifting and high heat flow environment of the Taupo Volcanic Zone, that allows magma otherwise bound within the crystal mush to be mobilised and erupted. We discuss the relationship between tectonics and the LdMVF magma system further in section 5.4.

\subsection{Relationship to eruption vents, deformation and tectonics}

To address the question of Singer et al. (2014) as to whether a crystal poor rhyolitic magma reservoir underlies the entire volcanic field, our model suggests that a body of crystal poor magma currently only exists under the southern portion of the LdMVF. To test the hypothesis that ring faulting at the reservoir margins has produced the surface pattern of vents encircling the lake (e.g. Singer et al., 2014, Figure 6), we compare our imaged magma reservoir to analytic and numerical models of volcanic ring fault growth. Yokoyama (2015) developed an analytic, shear fracture model, for the formation of parasitic vents due to a 
dilatation source representing a magma chamber, and found that vents forming along a ring fracture occur at a distance from the source of $r= \pm 0.82 \mathrm{D}$, where $\mathrm{D}$ is the depth to the source. For a magma reservoir at $3 \mathrm{~km}$ depth, this would indicate a maximum vent distance of around $2.5 \mathrm{~km}$ from the edge of the magma reservoir. Using numerical models, Gudmundsson et al. (1997) found that the maximum tensile stress at the free surface, was a distance of 1 to 2 times the chamber radius, from the centre of the chamber, depending on chamber geometry. The Nieblas $(r l n)$ vent is approximately $2.5 \mathrm{~km}$ from the southern edge of the imaged magma reservoir, or 2 times the reservoir radius from the centre, and was conceivably fed from the present magma system location. However, the remainder of the post-glacial rhyolite vents are farther away, suggesting the size of the present day reservoir is smaller, or in a different location to that which fed the other eruptions. Migration of the active, eruptible, portion of the larger reservoir system to the edges of the crystalline rim would allow for eruption of more distal vents via a ring fault model. Cole et al. (2010) also found magma migration is required to explain subsidence and eruptive trends within the Okataina Caldera and similar magma migration to distant vents has been suggested for Katmai-Novarupta (Hildreth, 1991) and at Rotorua-Kapenga calderas (Nairn, 2002). The higher density material associated with vents in the north west may represent solidified rhyolite and andesite dykes that fed these vents.

The spatial and depth extent of the magma system imaged at LdMVF in this study, correlates well with the extent of a $5 \mathrm{~km}$ deep sill modelled by Feigl et al. (2014) as the cause of the ongoing deformation (Figure 9). The base of our low density body lies at approximately the sill depth, so our model is consistent with a high silica magma reservoir being underplated by an injection of mafic magma, also required by thermodynamics as discussed previously. Our gravity model is not able to resolve the sill, as it is too deep (5 km) and too thin $(10 \mathrm{~m})$, and we calculate a gravity effect of $\sim 0.03 \mathrm{mGal}$. We observe that the low aspect ratio (width/height) of the magma reservoir diverges from the typical high aspect ratio commonly portrayed in theoretical models (e.g. 
Gregg et al., 2015) and suggests that a wider range of orientations should be considered in these models, especially for shallow systems. We propose that shallow reservoirs are influenced more by the regional horizontal stress regime, than by the depth of burial, resulting in a more vertically oriented system (e.g. Saxby et al., 2016). Indeed, the thin overburden, with frequent injection of heat and volatiles into the base of the system, likely leads to over-pressures being more regularly exceeded. This may help explain differences in eruption trends between LdMVF and deeper sourced systems like Taupo, where the magma storage zone is at a minimum 6-8 km deep (Charlier et al., 2005).

The LdMVF magma system is located adjacent to the Troncoso fault, a 20 $30 \mathrm{~km}$ long linear structure visible from satellite imagery. Although our gravity data are unable to map any displacement across the fault, focal mechanisms from an $8 \mathrm{~km}$ deep Mw 6.0 earthquake in June 2012 http://earthquake. usgs.gov/earthquakes/eventpage/usp000jmf2\#executive, $2 \mathrm{~km}$ west of the fault, suggest right lateral motion on a steeply eastward dipping fault plane. If the Troncoso fault was extended north-east into the lake, as unpublished magnetic data collected by the authors suggest, and connected to faults mapped on the north shore of the lake, then it would bound the western edge of the magma reservoir in a releasing bend. Extensional or strike-slip environments are common features of silicic systems elsewhere (e.g. Taupo, Okataina and Long Valley) and appear to play important roles in the formation of large magma reservoirs. Saxby et al. (2016) proposed that the accumulation and ascent of magma at the Ilopango caldera, El Salavdor, was similarly controlled by local and regional tectonic stress and that caldera collapse occurred during pull apart basin formation along the main strike slip tectonics of the region. However at the LdMVF, caldera collapse has not occurred since the 950 ka Bobadilla Caldera formation, so it is likely that tectonics, while important for controlling the shape and location of the magma reservoir, is not the only factor determining if caldera collapse occurs.

In addition to placing controls on the location and shape of magmatic reservoirs, faults may place important roles in the localisation of future eruptions. 
Strongly magnetic lineaments mapped in beneath the lake, are interpreted as dykes intruding along faults parallel to the dominant tectonic strike. Fault and magma reservoir interaction have been important in the control of other Andean silicic eruptions (e.g. Chaitén; Wicks et al., 2011), and should be considered as part of hazard assessment and monitoring at LdMVF. We suggest that further work is undertaken on the Troncoso and nearby faults, to characterise local and regional stress fields, and assess their influence on the magma reservoir location, geometry and possible future eruption sites.

\section{Conclusions}

A -19 mGal gravity anomaly at the Laguna del Maule volcanic field (LdMVF) can be explained by a shallow, $30 \mathrm{~km}^{3}$ magmatic reservoir, that contains at least $85 \%$ melt in the shallowest part, reducing to $<50 \%$ at the base of the system. This active reservoir sits within a $115 \mathrm{~km}^{3}$ partially to wholly crystallised $(>70$ $\%$ crystal) cumulate mush zone. Though we cannot image it, thermodynamic considerations require a compositional gradient of more mafic material at depth, to maintain inferred crystallinity and temperature conditions. Our data cannot be solely explained by a low density surface layer, although some low density surficial material is modelled, likely representing a shallow hydrothermal system. Nor can the data be explained by a density model which ignores the effects of the free volatile phase on lowering the total magma system density.

Thermodynamic modelling provides additional insights into the magma system over approaches that consider only the melt phase density. Crucially, we have determined the distribution of melt and crystal in the magma system and included the free vapour phase that may drive future explosive eruptions. This approach allows for a more comprehensive hazard determination than density models based only on the liquid phase. Additionally our modelling code offers a new open source approach to geophysical inversion, highly applicable to volcano studies.

The present day crystal poor reservoir does not underlie the extent of the 
post-glacial LdMVF vents, and stress models of dyke propagation from magma reservoirs require it to have moved over time to be in closer spatial proximity to older vents. Alternately, the present day magma system is smaller than that which formed the early post-glacial eruptions, or lateral migration of magma from older eruption vents to the present location has occurred. Intruded to extruded volume ratios suggest that the Las Nieblas $(r l n)$ eruption tapped $\sim 7 \%$ of the magma reservoir volume and that the post-glacial LdMVF is characterised by eruptions of small aliquots of magma from the top of a larger reservoir, rather than the evacuation and catastrophic collapse of the entire reservoir.

The reservoir lies directly above the modelled source of the ongoing deformation and supports the model of Le Mével et al. (2016) that the deformation is caused by injection of mafic magma into the base of a reservoir. Even though a large density contrast with the crust exists, we calculate that the magma reservoir is not over pressured, and that eruption due to buoyancy effects alone is unlikely. The western margin of the magma reservoir is in the hanging wall of the hypothesized Troncoso fault and we suggest that the location and orientation of the reservoir may be influenced by local tectonics which may also provide the trigger required for the next eruption.

The presence of a shallow, large volume of volatile rich magma stored at near liquidus conditions, adjacent to a regional scale fault has important implications for the onset of any future eruptive activity. As such, our 3D density model of the LdMVF magma reservoir provides essential context to interpret monitoring data, and contributes to greater understanding of the ongoing dynamics of this unique area of volcanism. Finally, our combined gravity and thermodynamic analysis, provides a framework for richer interpretation of gravity data from silicic magma systems worldwide.

\section{Acknowledgements}

We thank Basil Tikoff and University of Wisconsin-Madison for loan of the gravity meters and logistical support. We acknowledge the many field assistants 
involved with data collection, especially Daniel Diaz and students from Universidad de Chile-Santiago, Daniel Cabrera, Valentina Reyes, Ariel Figueroa, Daniella Calle, Gustavo Peréz, as well as Alex de Mets, Swetha Venugopal, and Hélène Le Mével. We also thank Hélène Le Mével for discussions on the gravity model. We thank Diego Lillo and Sergio Morales from OVDAS, Sernageomin, for field assistance, Loreto Cordova for the CGPS base station data and Carlos Cardona for the 1D velocity model. We acknowledge Energy Development Corporation, Chile, for sharing their gravity dataset. Thanks to Andreas Tassara for bathymetry data and to Sylvain Bonvalot and Bureau Gravimetric International for establishing the absolute gravity stations. Thanks to Nathan Andersen and Brad Singer for whole rock analyses, discussions on the MELTS results and their implications, as well as to Natalia Deligne for discussions on presentation of those results. We wish to thank Don Luis Torres Jara, the Alcade de Mar, for his hospitality, nautical assistance and trucha ceviche. Field work was funded by NSF Integrated Earth Systems grant EAR-1411779 and EAR-1322595. C.M is supported by GNS Science Core Funding, EQC New Zealand, Mitacs Accelerate Canada and Mira Geoscience. We gratefully acknowledge two anonymous reviewers and the editorial advice of Tamsin Mather that improved this manuscript.

\section{References}

Allan, A.S.R., Wilson, C.J.N., Millet, M.A., Wysoczanski, R.J., 2012. The invisible hand: Tectonic triggering and modulation of a rhyolitic supereruption. Geology 40, 563-566. doi:10.1130/G32969.1.

Andersen, N.L., Singer, B.S., Jicha, B.R., Beard, B.L., Johnson, C.M., Licciardi, J.M., 2016. Pleistocene to Holocene growth of a large upper crustal rhyolitic magma reservoir beneath the active Laguna del Maule volcanic field, central Chile. Journal of Petrology .

Bachmann, O., Bergantz, G., 2008. The magma reservoirs that feed supereruptions. Elements 4,17-21. doi:10.2113/GSELEMENTS .4.1.17. 
Bachmann, O., Bergantz, G.W., 2004. On the Origin of Crystal-poor Rhyolites: Extracted from Batholithic Crystal Mushes. Journal of Petrology 45, 15651582. doi:10.1002/2014GB005021.

Bachmann, O., Miller, C.F., de Silva, S.L., 2007. The volcanic-plutonic connection as a stage for understanding crustal magmatism. Journal of Volcanology and Geothermal Research 167,1-23. doi:10.1016/j.jvolgeores.2007.08. 002.

Battaglia, M., Poland, M.P., Kauahikaua, J., 2012. GTools: An interactive computer program to process gravity data for high resolution applications, in: AGU Fall Meeting, pp. GP43B-1143.

Brocher, T.M., 2005. Empirical Relations between Elastic Wavespeeds and Density in the Earth's Crust. Bulletin of the Seismological Society of America 95, 2081-2092. URL: http://bssa.geoscienceworld.org/cgi/doi/10.1785/ 0120050077, doi:10.1785/0120050077.

Camacho, A.G., Fernández, J., Gottsmann, J., 2011. The 3-D gravity inversion package GROWTH2.0 and its application to Tenerife Island, Spain. Computers \& Geosciences 37, 621-633. URL: http://linkinghub.elsevier.com/ retrieve/pii/S0098300411000264, doi:10.1016/j. cageo.2010.12.003.

Carrevedo, M.L., Frugone, M., Latorre, C., Maldonado, a., Bernardez, P., Prego, R., Cardenas, D., Valero-Garces, B., 2015. A 700-year record of climate and environmental change from a high Andean lake: Laguna del Maule, central Chile (36S). The Holocene 25, 956-972. URL: http://hol.sagepub.com/ cgi/doi/10.1177/0959683615574584, doi:10.1177/0959683615574584.

Cashman, K.V., Giordano, G., 2014. Calderas and magma reservoirs. Journal of Volcanology and Geothermal Research 288, 28-45. URL: http: //linkinghub.elsevier.com/retrieve/pii/S0377027314002868, doi:10. 1016/j . jvolgeores . 2014.09.007. 
Castro, J.M., Dingwell, D.B., 2009. Rapid ascent of rhyolitic magma at Chaitén Volcano, Chile. Nature 461, 780-783. URL: http://www.ncbi.nlm.nih. gov/pubmed/19812671, doi:10.1038/nature08458.

Castro, J.M., Schipper, C.I., Mueller, S.P., Militzer, a.S., Amigo, A., Parejas, C.S., Jacob, D., 2013. Storage and eruption of near-liquidus rhyolite magma at Cordon Caulle, Chile. Bulletin of Volcanology 75, 1-17. doi:10.1007/ s00445-013-0702-9.

Charlier, B.L.A., Wilson, C.J.N., Lowenstern, J.B., Blake, S., van Calsteren, P.W., Davidson, J.P., 2005. Magma generation at a large, hyperactive silicic volcano (Taupo, New Zealand) revealed by U-Th and U-Pb systematics in zircons. Journal of Petrology 46, 3-32. doi:10.1093/petrology/egh060.

Cockett, R., Kang, S., Heagy, L.J., Pidlisecky, A., Oldenburg, D.W., 2015. SimPEG: An open source framework for simulation and gradient based parameter estimation in geophysical applications. Computers \& Geosciences 85, 142-154. URL: http://www.sciencedirect.com/science/article/pii/ S009830041530056X, doi:10.1016/j.cageo.2015.09.015.

Cole, J.W., Spinks, K.D., Deering, C.D., Nairn, I.A., Leonard, G.S., 2010. Volcanic and structural evolution of the Okataina Volcanic Centre; dominantly silicic volcanism associated with the Taupo Rift, New Zealand. Journal of Volcanology and Geothermal Research 190, 123-135. URL: http://dx.doi.org/10.1016/j.jvolgeores.2009.08.011, doi:10. 1016/j.jvolgeores.2009.08.011.

Cordell, D., Unsworth, M., Díaz, D., Pavez, M., Blanco, B., 2015. Magnetotelluric Studies of the Laguna del Maule Volcanic Field, Central Chile, in: AGU Fall Meeting, pp. V43B-3136.

Davy, B.W., Caldwell, T.G., 1998. Gravity, magnetic and seismic surveys of the caldera complex, Lake Taupo, North Island, New Zealand. Journal of Volcanology and Geothermal Research 81, 69-89. doi:10.1016/S0377-0273(97) 00074-7. 
DeNosaquo, K.R., Smith, R.B., Lowry, A.R., 2009. Density and lithospheric strength models of the Yellowstone-Snake River Plain volcanic system from gravity and heat flow data. Journal of Volcanology and Geothermal Research 188, 108-127. URL: http://dx.doi.org/10.1016/j.jvolgeores.2009.08. 006, doi:10.1016/j.jvolgeores.2009.08.006.

Feigl, K.L., Le Mevel, H., Tabrez Ali, S., Cordova, L., Andersen, N.L., DeMets, C., Singer, B.S., 2014. Rapid uplift in Laguna del Maule volcanic field of the Andean Southern Volcanic zone (Chile) 2007-2012. Geophysical Journal International 196, 885-901. URL: http://gji.oxfordjournals.org/cgi/ doi/10.1093/gji/ggt438, doi:10.1093/gji/ggt438.

Gonnermann, H.M., Manga, M., 2005. Nonequilibrium magma degassing: Results from modeling of the ca. 1340 A.D. eruption of Mono Craters, California. Earth and Planetary Science Letters 238, 1-16. doi:10.1016/j.epsl.2005. 07.021.

Gonnermann, H.M., Manga, M., 2012. Modeling Volcanic Processes: The Physics and Mathematics of Volcanism.

Gregg, P.M., Grosfils, E.B., de Silva, S.L., 2015. Catastrophic caldera-forming eruptions II: The subordinate role of magma buoyancy as an eruption trigger. Journal of Volcanology and Geothermal Research 305, 100-113. doi:10.1016/ j.jvolgeores.2015.09.022.

Gualda, G.A.R., Ghiorso, M.S., 2015. MELTS_Excel: A Microsoft Excelbased MELTS interface for research and teaching of magma properties and evolution. Geochemistry,Geophysics,Geosystems 16, 315-324. doi:10.1002/ 2014GC005545. Received.

Gudmundsson, a., Marti, J., Turon, E., 1997. Stress Fields Generating Ring Faults In Volcanoes. Geophysical Research Letters 24, 1559-1562. doi:10. 1029/97GL01494. 
Hildreth, W., 1991. The timing of caldera collapse at Mount Katmai in response to magma withdrawal toward Novarupta. Geophysical Research Letters 18, 1541-1544. URL: http://doi.wiley.com/10.1029/91GL01083, doi:10.1029/91GL01083.

Hildreth, W., Godoy, E., Fierstein, J., Singer, B.S., 2010. Laguna del Maule volcanic field: Eruptive history of a Quaternary basalt to rhyolite distributed volcanic field on the Andean range crest in central Chile. Servicio Nacional de Geologia y Mineria, Bolletin 63, 145.

Hinze, W.J., Aiken, C., Brozena, J., Coakley, B., Dater, D., Flanagan, G., Forsberg, R., Hildenbrand, T., Keller, G.R., Kellogg, J., Kucks, R., Li, X., Mainville, A., Morin, R., Pilkington, M., Plouff, D., Ravat, D., Roman, D., Urrutia-Fucugauchi, J., Veronneau, M., Webring, M., Winester, D., 2005. New standards for reducing gravity data: The North American gravity database. Geophysics 70, J25-J32. doi:10.1190/1.1988183.

Humphreys, E., Clayton, R.W., 1988. Adaptation of back projection tomography to seismic travel time problems. Journal of Geophysical Research 93, 1073. URL: http://doi.wiley.com/10.1029/JB093iB02p01073, doi:10.1029/JB093iB02p01073.

Huppert, H.E., Sparks, R.S.J., Turner, J.S., 1982. Effects of volatiles on mixing in calc-alkaline magma systems. Nature 297, 554-557. doi:10 .1038/297554a0.

Jay, J., Costa, F., Pritchard, M., Lara, L., Singer, B., Herrin, J., 2014. Locating magma reservoirs using InSAR and petrology before and during the 2011 - 2012 Cordón Caulle silicic eruption. Earth and Planetary Science Letters 395, 254-266. URL: http://linkinghub.elsevier.com/retrieve/ pii/S0012821X14001988, doi:10.1016/j.epsl.2014.03.046.

Kane, M.F., Mabey, D.R., Brace, R.l., 1976. A Gravity and Magnetic Investigation of the Long Valley Caldera, Mono County, California. Journal of Geophysical Research 81, 754-762. 
Le Mével, H., Feigl, K.L., Córdova, L., DeMets, C., Lundgren, P., 2015. Evolution of unrest at Laguna del Maule volcanic field (Chile) from InSAR and GPS measurements, 2003 to 2014. Geophysical Research Letters 42, 6590-6598. URL: http://doi.wiley.com/10.1002/2015GL064665, doi:10.1002/2015GL064665.

Le Mével, H., Gregg, P.M., Feigl, K.L., 2016. Magma injection into a longlived reservoir to explain geodetically measured uplift: Application to the 2007-2014 unrest episode at Laguna del Maule volcanic field, Chile. Journal of Geophysical Research: Solid Earth 121, 6092-6108. URL: http://doi. wiley.com/10.1002/2016JB013066, doi:10.1002/2016JB013066.

Malfait, W.J., Seifert, R., Petitgirard, S., Perrillat, J.P., Mezouar, M., Ota, T., Nakamura, E., Lerch, P., Sanchez-Valle, C., 2014. Supervolcano eruptions driven by melt buoyancy in large silicic magma chambers. Nature Geoscience 7, 122-125. URL: http://www.nature.com/ngeo/journal/v7/n2/full/ ngeo2042.html\$\delimiter"026E30F\$nhttp: //www . nature.com/ngeo/ journal/v7/n2/pdf/ngeo2042.pdf, doi:10.1038/ngeo2042.

Marsh, B.D., 1981. On the crystallinity, probability of occurrence, and rheology of lava and magma. Contributions to Mineralogy and Petrology 78, 85-98. doi:10.1007/BF00371146.

Masturyono, McCaffrey, R., Wark, D.A., Roecker, S.W., Fauzi, Ibrahim, G., Sukhyar, 2001. Distribution of magma beneath the Toba caldera complex, north Sumatra, Indonesia, constrained by three-dimensional $\mathrm{P}$ wave velocities, seismicity, and gravity data. Geochem. Geophys. Geosyst. 2, doi:10.1029/2000GC000096. doi:10.1029/2000GC000096.

Miller, C.A., Williams-Jones, G., 2016. Internal structure and volcanic hazard potential of Mt Tongariro, New Zealand, from 3D gravity and magnetic models. Journal of Volcanology and Geothermal Research 319, 12-28. URL: http: //linkinghub.elsevier.com/retrieve/pii/S0377027316300245, doi:10. 1016/j.jvolgeores. 2016.03.012. 
Nairn, I.A., 2002. Geology of the Okataina Volcanic Centre. Technical Report. Institute of Geological and Nuclear Sciences.

Nettleton, L.L., 1939. Determination of density for reduction of gravimeter observations. Geophysics 4. doi:10.1190/1.1437088.

Parasnis, D., 1966. Mining Geophysics. Elsevier, Amsterdam-London-New York.

del Potro, R., Díez, M., Blundy, J., Camacho, A.G., Gottsmann, J., 2013. Diapiric ascent of silicic magma beneath the Bolivian Altiplano. Geophysical Research Letters 40, 2044-2048. URL: http://doi.wiley.com/10.1002/ grl.50493, doi:10.1002/grl.50493.

Pritchard, M.E., Gregg, P.M., 2016. Geophysical Evidence for Silicic Crustal Melt in the Continents: Where, What Kind, and How Much? Elements 12, 121-127. URL: http://elements.geoscienceworld.org/lookup/doi/10. 2113/gselements.12.2.121, doi:10.2113/gselements.12.2.121.

Reid, M.R., Coath, C.D., Mark Harrison, T., McKeegan, K.D., 1997. Prolonged residence times for the youngest rhyolites associated with Long Valley Caldera:230Th238U ion microprobe dating of young zircons. Earth and Planetary Science Letters 150, 27-39. doi:10.1016/S0012-821X(97)00077-0.

Rucker, C., Günther, T., Wagner, F., 2015. PyGIMLi - Eine Open Source Python Bibliothek zur Inversion und Modellierung in der Geophysik, in: Jahrestagung der Deutschen Geophysikalischen Gesellschaft (DGG), Hannover.

Saxby, J., Gottsmann, J., Cashman, K., Gutiérrez, E., 2016. Magma storage in a strike-slip caldera. Nature Communications 7, 12295. URL: http://www. nature.com/doifinder/10.1038/ncomms12295, doi:10.1038/ncomms12295.

Singer, B., Andersen, N., Le Mevel, H., Feigl, K., DeMets, C., Tikoff, B., Thurber, C., Jicha, B., Cardona, C., Cordova, L., Gil, F., Unsworth, M., 
Williams-Jones, G., Miller, C., Fierstein, J., Hildreth, W., Vazquez, J., 2014. Dynamics of a large, restless , rhyolitic magma system at Laguna del Maule, southern Andes, Chile. GSA Today 24, 4-10. doi:10.1130/GSATG216A.1.

Sparks, R.S.J., Huppert, H.E., 1984. Density changes during the fractional crystallization of basaltic magmas: fluid dynamic implications. Contributions to Mineralogy and Petrology 85, 300-309. doi:10.1007/BF00378108.

Sun, J., Li, Y., 2014. Adaptive lp inversion for simultaneous recovery of both blocky and smooth feature in geophysical model. Geophysical Journal International 197, 882-899.

Sutton, A.N., Blake, S., Wilson, C.J.N., Charlier, B.L.A., 2000. Late Quaternary evolution of a hyperactive rhyolite magmatic system: Taupo volcanic centre, New Zealand. Journal of the Geological Society, London 157, 537-552. URL: http://dx.doi.org/10.1144/jgs.157.3.537, doi:10.1144/ jgs.157.3.537.

Talwani, M., Ewing, M., 1960. Rapid computation of gravitational attraction of three-dimensional bodies of arbitrary shape. Geophysics 25, 203-225.

Uieda, L., Jr, V.C.O., Barbosa, V.C.F., 2013. Modeling the Earth with Fatiando a Terra, in: van der Walt, S., Millman, J., Huff, K. (Eds.), Proceedings of the 12th Python in Science Conference, pp. 96-103.

Wallace, P.J., Anderson, A., T., Davis, A., M., 1995. Quantification of preeruptive exsolved gas contents in silicic magmas. doi:10.1038/377612a0.

White, S.M., Crisp, J.A., Spera, F.J., 2006. Long-term volumetric eruption rates and magma budgets. Geochemistry, Geophysics, Geosystems 7. URL: http: //onlinelibrary .wiley.com/doi/10.1029/2005GC001002/fullhttp: //doi.wiley.com/10.1029/2005GC001002, doi:10.1029/2005GC001002.

Wicks, C., de la Llera, J.C., Lara, L.E., Lowenstern, J., 2011. The role of dyking and fault control in the rapid onset of eruption at Chaitén volcano, Chile. 
920

921

922

923

924

Nature 478, 374-377. URL: http://dx.doi.org/10.1038/nature10541, doi:10.1038/nature10541.

Wilson, C.J.N., 1993. Stratigraphy, chronology, styles and dynamics of late Quaternary eruptions from Taupo volcano, New Zealand. Philosophical transactions. Series A, Mathematical, physical, and engineering sciences 343, 205306.

Wilson, C.J.N., Charlier, B.L.A., 2009. Rapid rates of magma generation at contemporaneous magma systems, taupo volcano, New Zealand: Insights from U-Th model-age spectra in Zircons. Journal of Petrology 50, 875-907. doi:10.1093/petrology/egp023.

Yokoyama, I., 2015. Eruption patterns of parasitic volcanoes. Annals of Geophysics 58. doi:10.4401/ag-6557. 


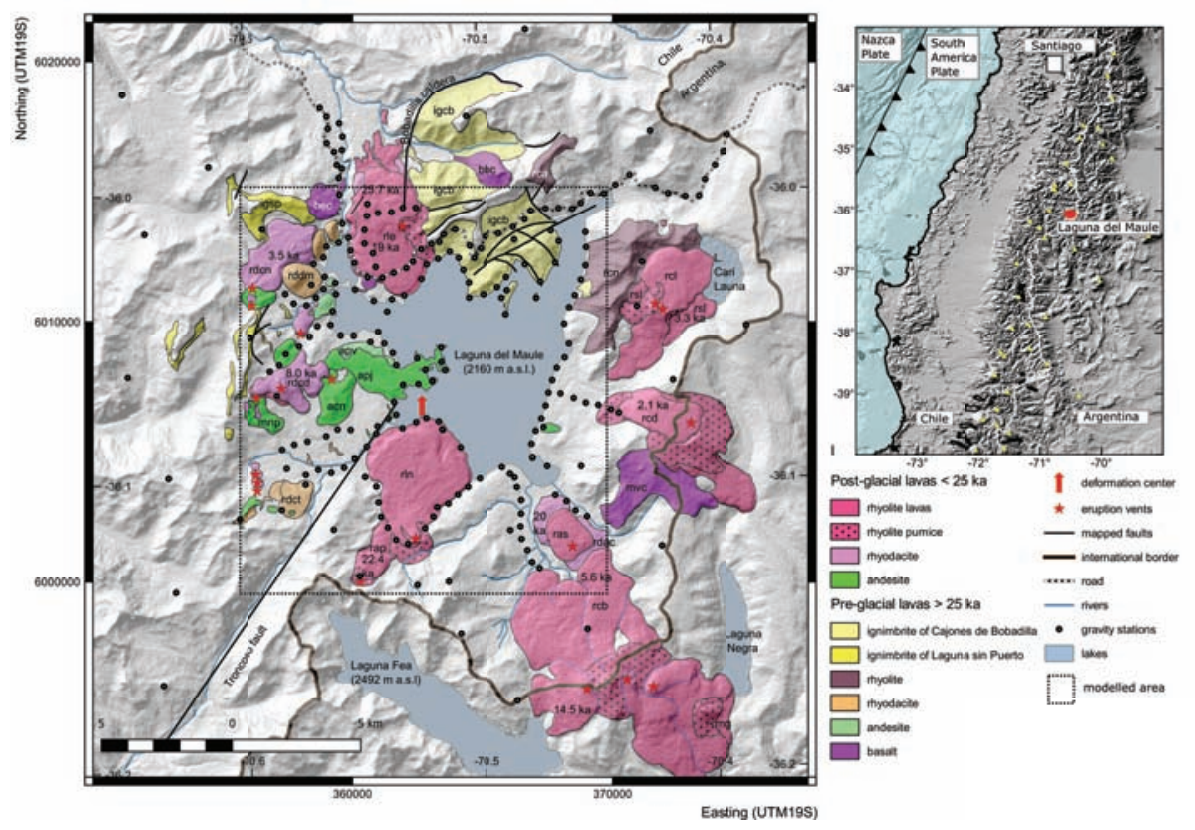

Figure 1: Simplified geology map of the central basin of the LdMVF (after Hildreth et al., 2010). Gravity station locations are shown as black dots. The red arrow indicates the centre of inflation from Feigl et al. (2014). Ages are from ${ }^{40} \mathrm{Ar} /{ }^{39} \mathrm{Ar}$ ratios (Andersen et al., 2016) and red stars show post-glacial vents. The dashed black box shows the outline of the modelled area. The smaller location map shows Laguna del Maule volcanic field as a red ellipse, with other Holocene volcanoes as yellow triangles. 

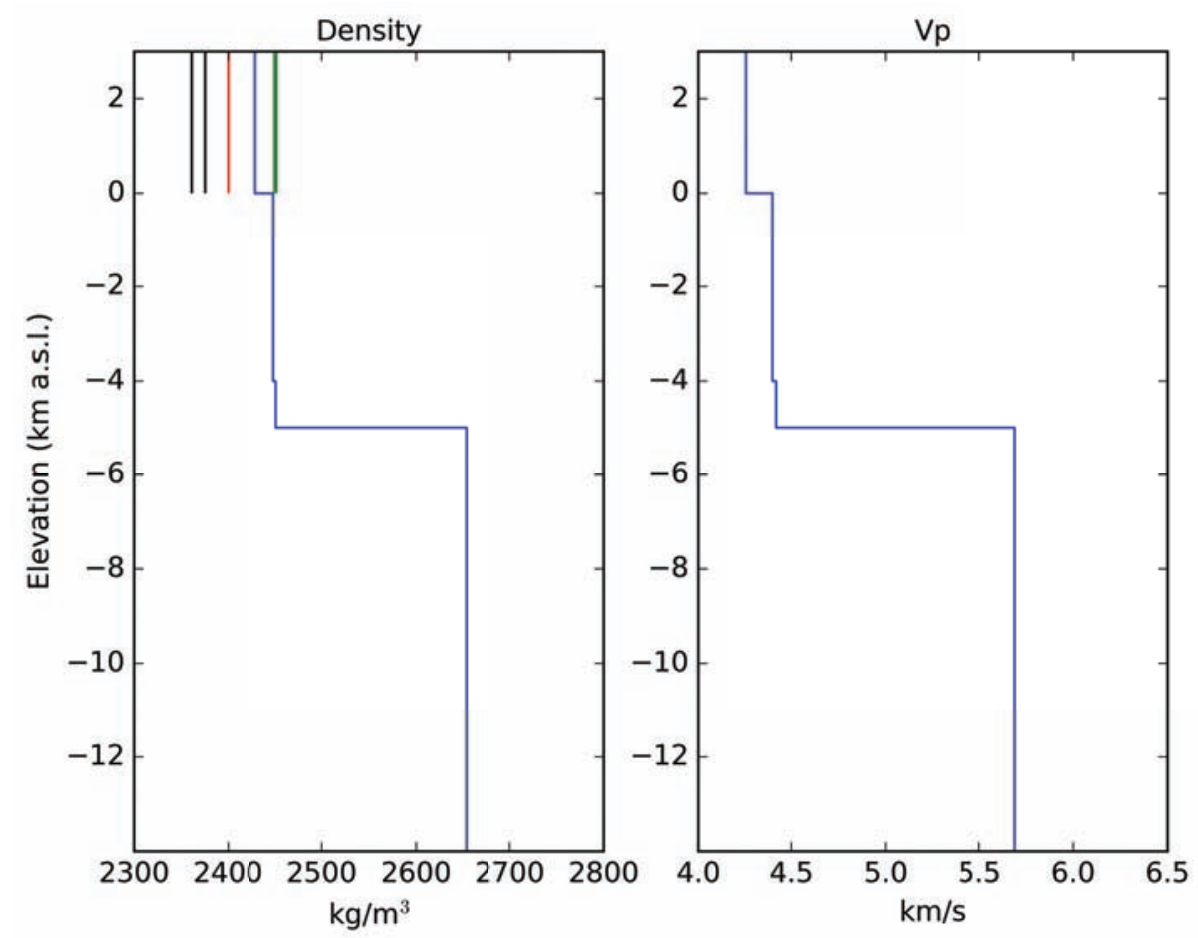

Figure 2: Bulk density (blue line) derived from 1D Observatorio Volcanologico de Los Andes del Sur (OVDAS) seismic velocity model (Vp plot, right) using the relationships of Brocher (2005). The density plot shows the results of the Nettleton and Parasnis density determinations from our gravity data in black, whilst the equivalent density determinations from a neighbouring commercial gravity dataset are shown in green. The correction density chosen for this study $\left(2400 \mathrm{~kg} / \mathrm{m}^{3}\right)$ is in red. 

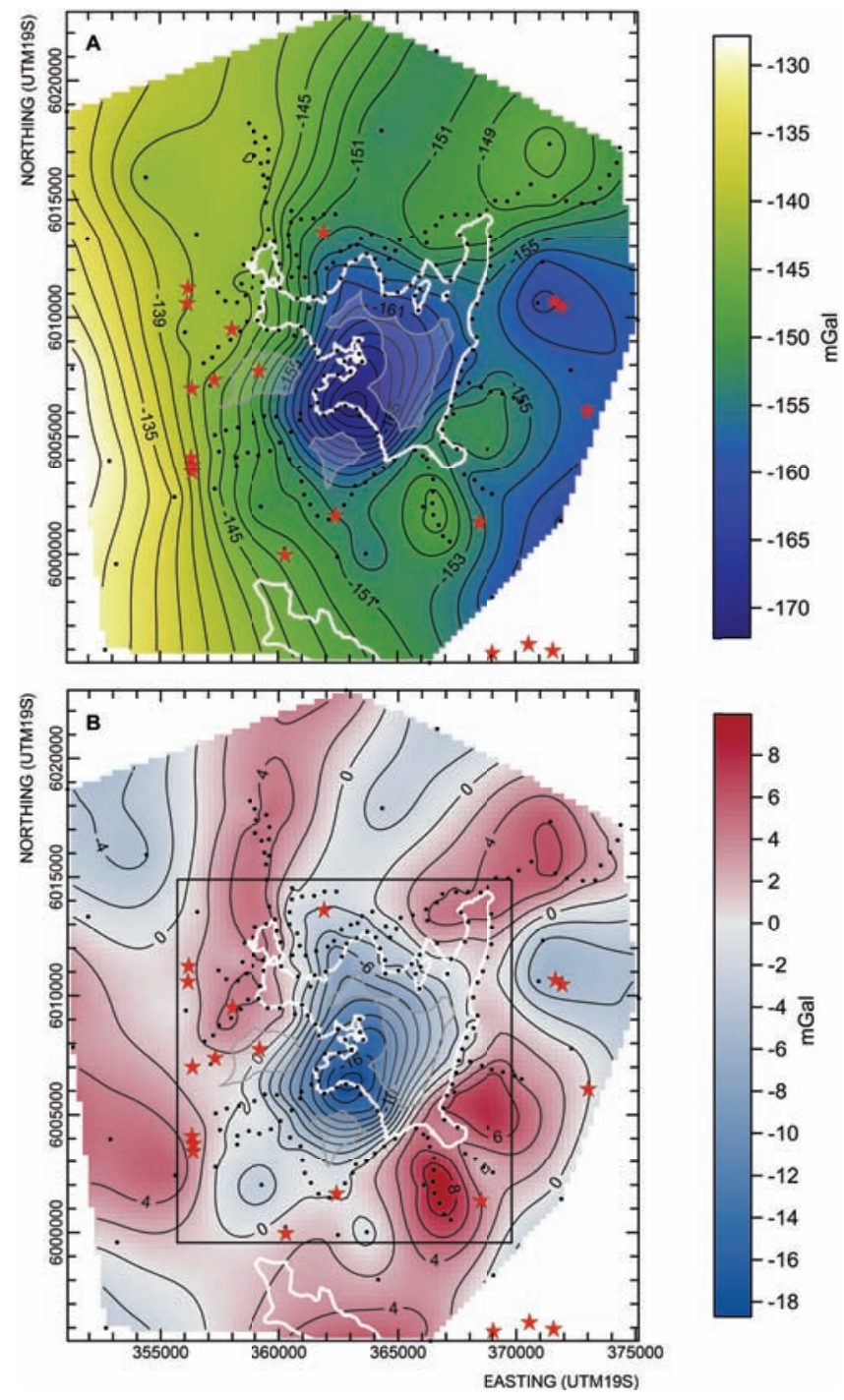

Figure 3: A) Bouguer gravity anomaly. B) Residual gravity anomaly after removal of a third order polynomial surface from the Bouguer data. The black box in B is the area modelled. Red stars are post-glacial eruption vents. The shorelines of Laguna del Maule and Laguna Fea are shown in white. Areas of the main anomaly shaded in grey are poorly constrained by the gravity observations and rely on interpolated data. 

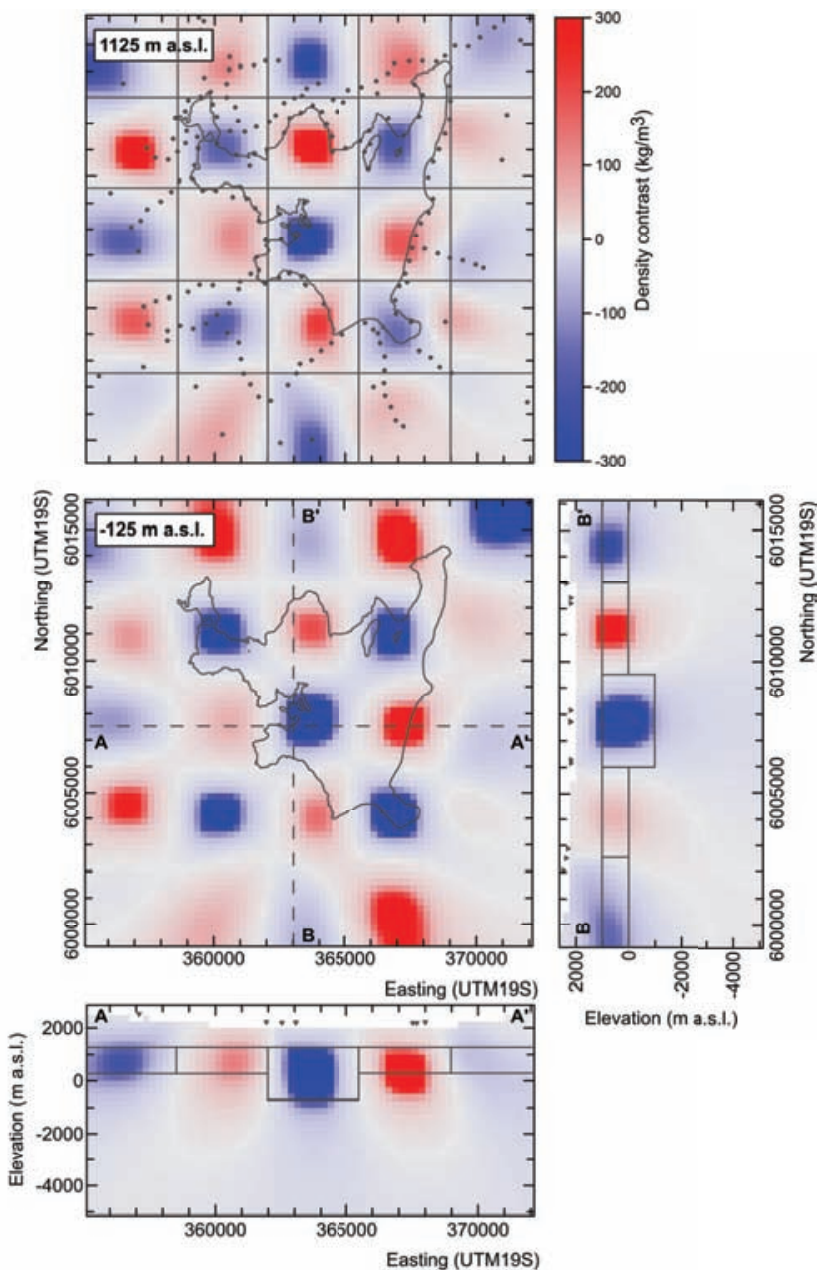

Elevation ( $m$ a.s.1.)

Figure 4: Elevation and depth slices from the checkerboard test at $1125 \mathrm{~m}$ a.s.l. (top) and $-125 \mathrm{~m}$ a.s.l. (lower). The checkerboard grid is shown in the $1125 \mathrm{~m}$ a.s.l. slice and also in the cross sections. The outline of the lake is shown in grey, while gravity stations are shown as dots and triangles (in cross sections). 

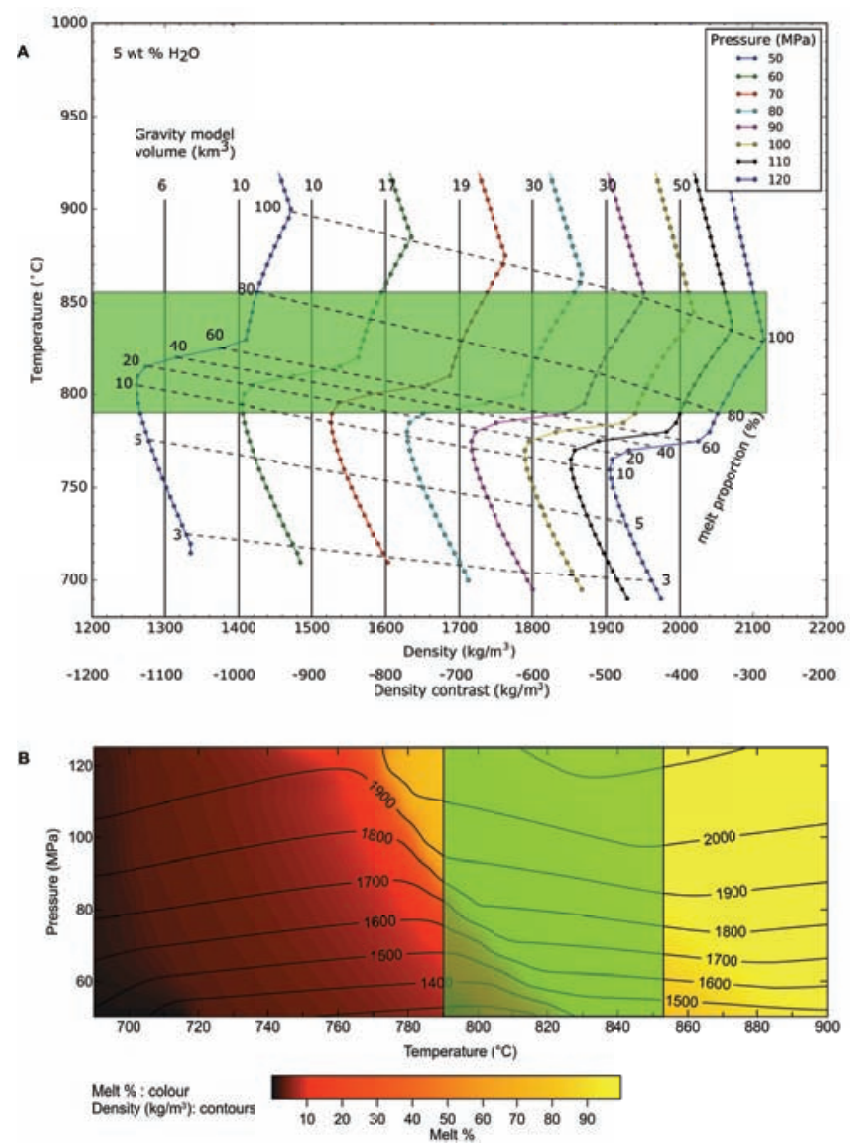

Figure 5: A) Plot of magma temperature vs density for a representative rhyolite magma, calculated using MELTS. The plot shows the results from 50 to $120 \mathrm{MPa}$ at 5 wt $\% \mathrm{H}_{2} \mathrm{O}$. Annotations include the proportion of liquid melt (dashed lines), gravity model volumes at each density contrast (solid black lines). Densities are the total magma system density, including liquid, crystal and free volatile phases. The green shaded area shows the magmatic temperature range from Fe-Ti oxide geothermometers (Andersen et al., 2016). B) Plot of magma density (contour lines in $\mathrm{kg} / \mathrm{m}^{3}$ ) and melt percent (colour gradient), as a function of pressure and temperature. The green rectangle shows the magmatic temperature range from Fe-Ti oxides, as in A. 


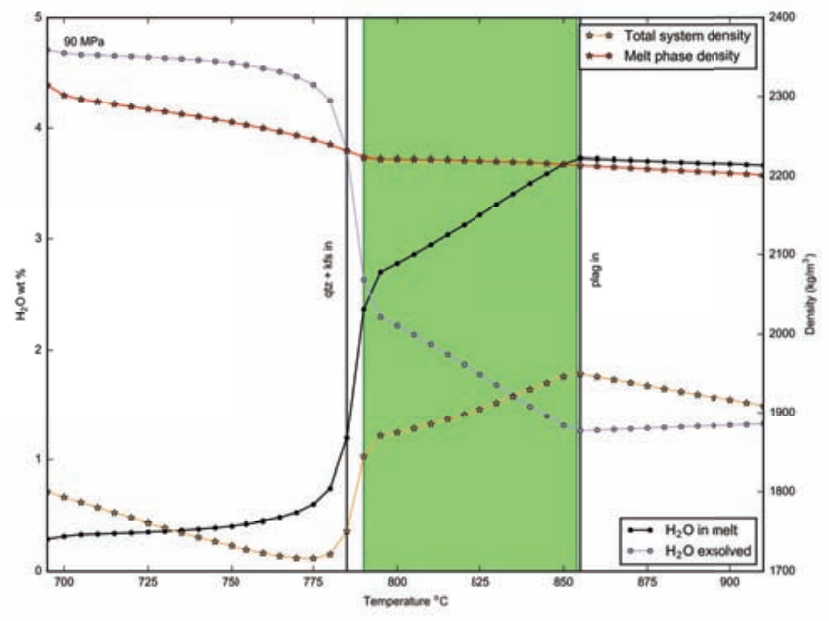

Figure 6: Phase diagram showing the evolution of $\mathrm{H}_{2} \mathrm{O}$ in the system as a function of temperature (dark blue and grey lines). The yellow and red lines show the corresponding density evolution of the total system (yellow) and liquid phase (red) and shows the large density difference caused by the exsolution of $\mathrm{H}_{2} \mathrm{O}$. The green shaded box highlights the magma temperatures derived by Fe-Ti geothermometry (Andersen et al., 2016). The vertical black lines show the temperatures at which feldspar and then quartz and K feldspar appear. The quartz, $\mathrm{K}$ feldspar crystallisation point is below the observed temperature range and explains the lack of quartz and $\mathrm{K}$ feldspar in LdMVF rhyolites. 

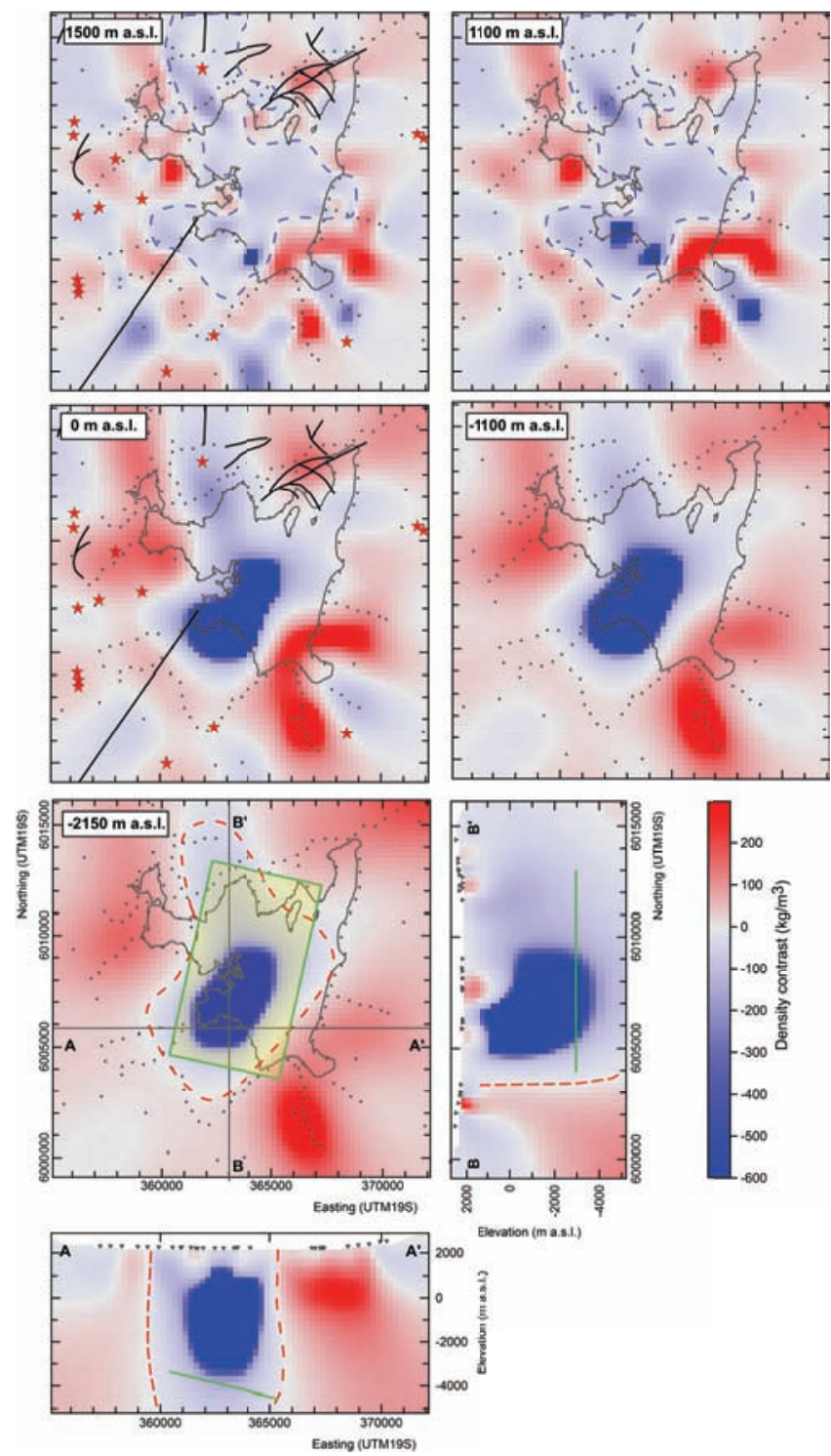

Figure 7: Elevation slices and cross sections from the inversion model with density contrast +300 to $-600 \mathrm{~kg} / \mathrm{m}^{3}$. The outline of the lake is shown in grey, while gravity stations are shown as grey dots and triangles (in cross sections). Mapped faults are shown as black lines and post-glacial eruption vents are shown as red stars in the $1500 \mathrm{~m}$ and $0 \mathrm{~m}$ a.s.l. slices. The dashed blue line in slices $1500 \mathrm{~m}$ and $1100 \mathrm{~m}$ a.s.l. represents a low density surface layer similar to the conductive surface layer imaged by Cordell et al. (2015). The dashed red line in the $-2150 \mathrm{~m}$ a.s.l. slice shows the lower density contrast rim of the main low density body, while the green outlined rectangle indicates the projection of the sill modelled by Feigl et al. (2014) at $5 \mathrm{~km}$ depth (-3000 m a.s.l.). 


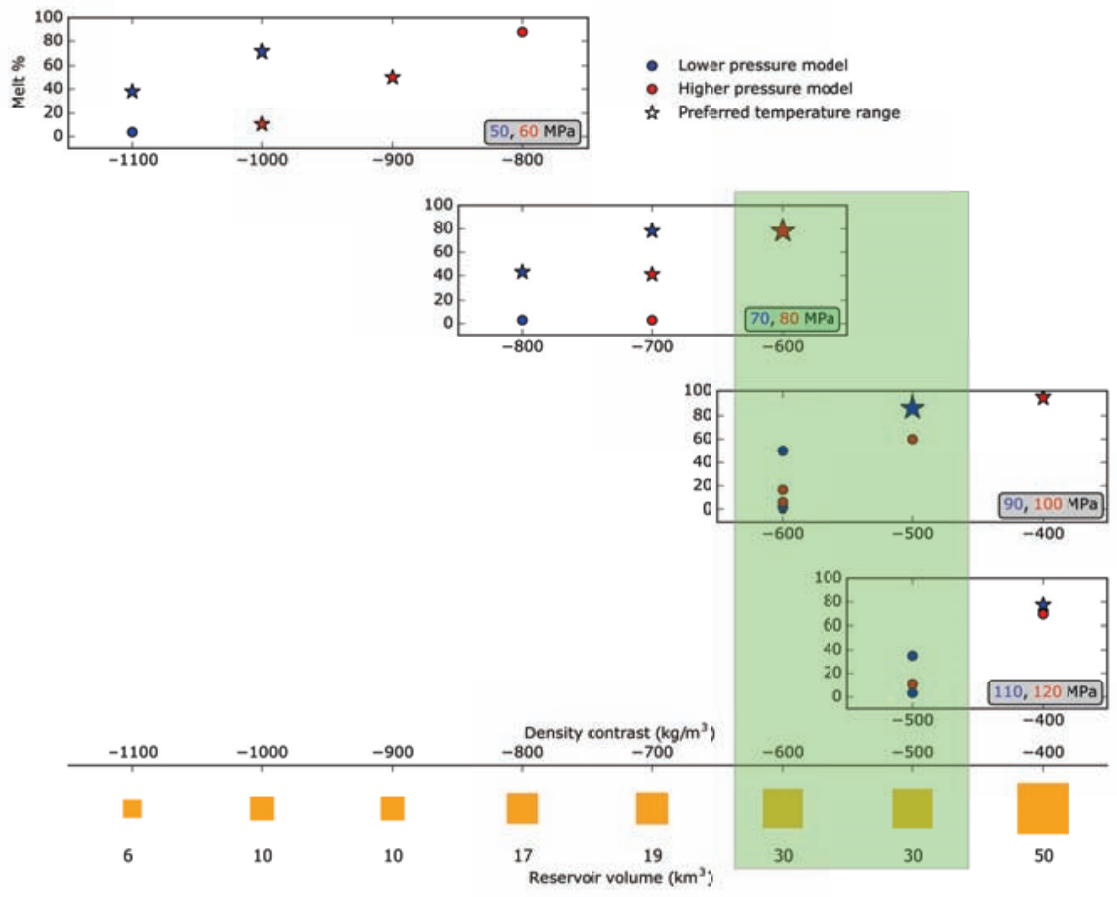

Figure 8: Summary of model volumes and proportion of melt possible for each model. The four boxes show the proportion of melt for a pair of pressure ranges, with the lower pressure model shown as blue dots and the higher pressure model as red dots. Star symbols indicate the models that fall within the temperature range of pre-eruptive temperatures determined by Fe-Ti oxide geothermometry by Andersen et al. (2016), (see Figure 5). The volume of the gravity model for each density contrast is shown along the base of the plot. Note that at some density contrasts, a range of pressures at which various proportions of melt exist are possible. Our preferred suite of models is highlighted in green shading and the four larger stars show the models that are most likely when all constraints are considered. 


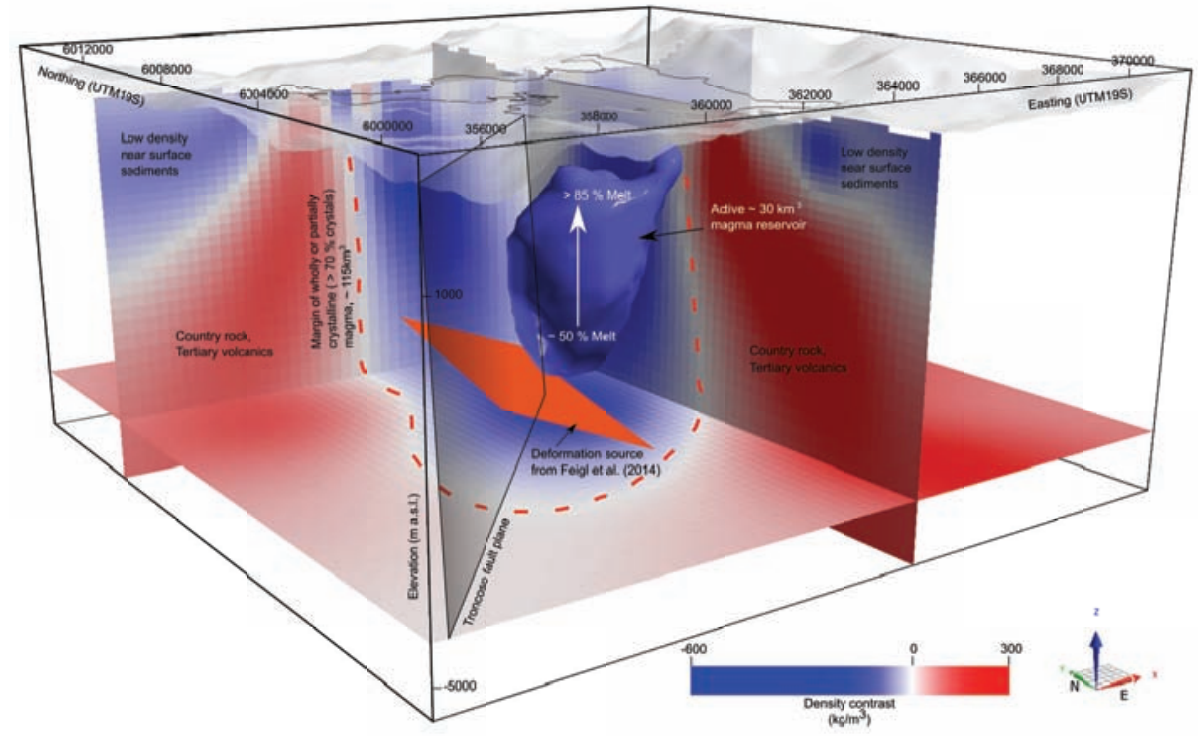

Figure 9: $3 \mathrm{D}$ view of the preferred $-600 /+300 \mathrm{~kg} / \mathrm{m}^{3}$ density contrast model, illustrating the LdMVF magma system. The isosurface (volume $=30 \mathrm{~km}^{3}$ ) shown in purple is $-600 \mathrm{~kg} / \mathrm{m}^{3}$, and sits within a $115 \mathrm{~km}^{3}$ body of -100 to $-200 \mathrm{~kg} / \mathrm{m}^{3}$ density contrast (dashed red line) interpreted to represent a partially ( $>70 \%$ crystal) to wholly crystallised mush surrounding an active magma reservoir that contains 50 to $>85 \%$ melt. The orange plane is the sill modelled by Feigl et al. (2014) to explain the current deformation episode and the grey shaded vertical plane is the Troncoso fault. The outline of the lake is shown superimposed on the topography. 


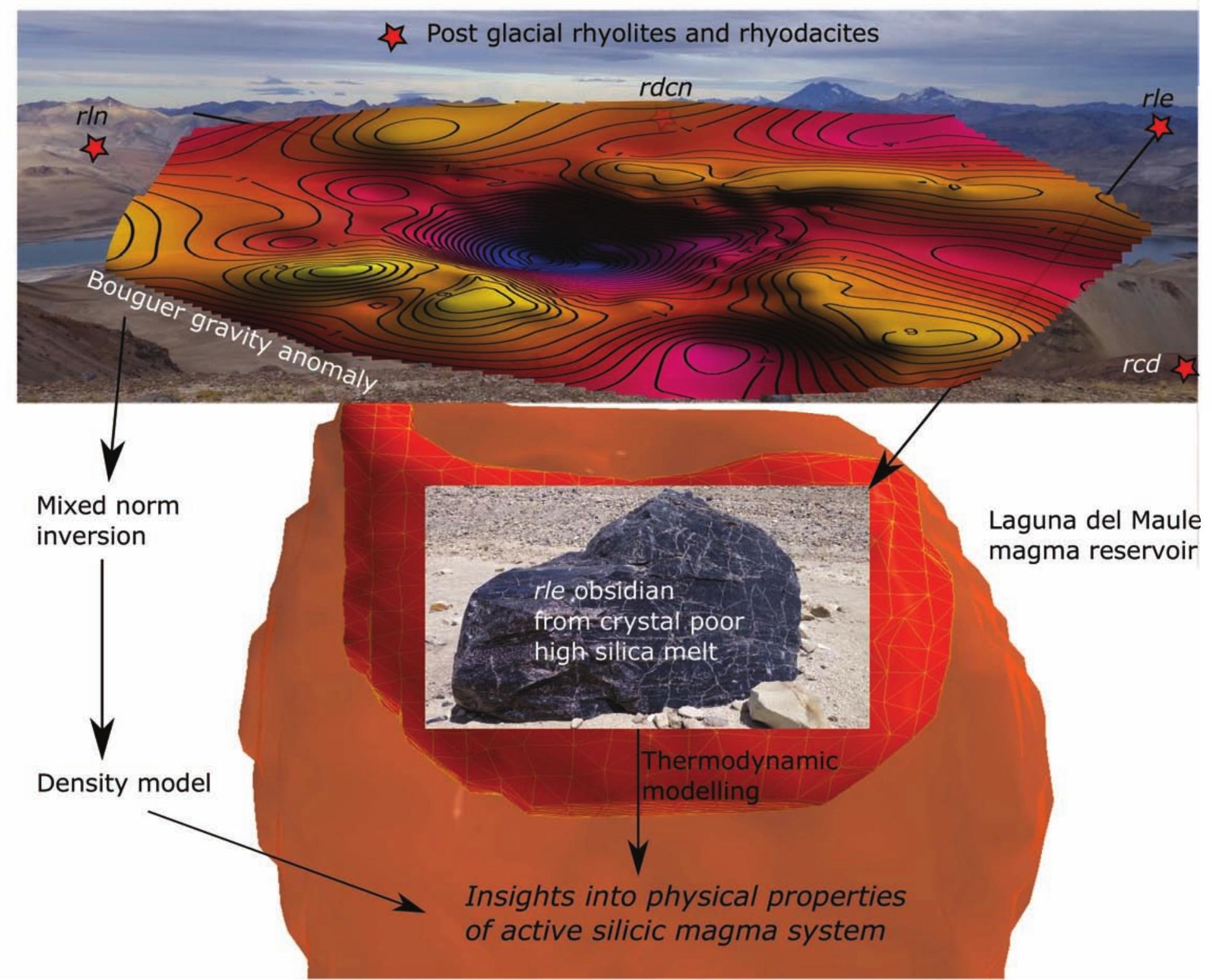

\section{Graphical Abstract}

$₹$ Post glacial rhyolites and rhyodacites

)

$2 \infty_{2}$

gravinas

momaly

inversion

Insights into physical properties of active silicic magma system 
900 volume $\left(\mathrm{km}^{3}\right)$

(

800

750

10

$610 \$ 10$
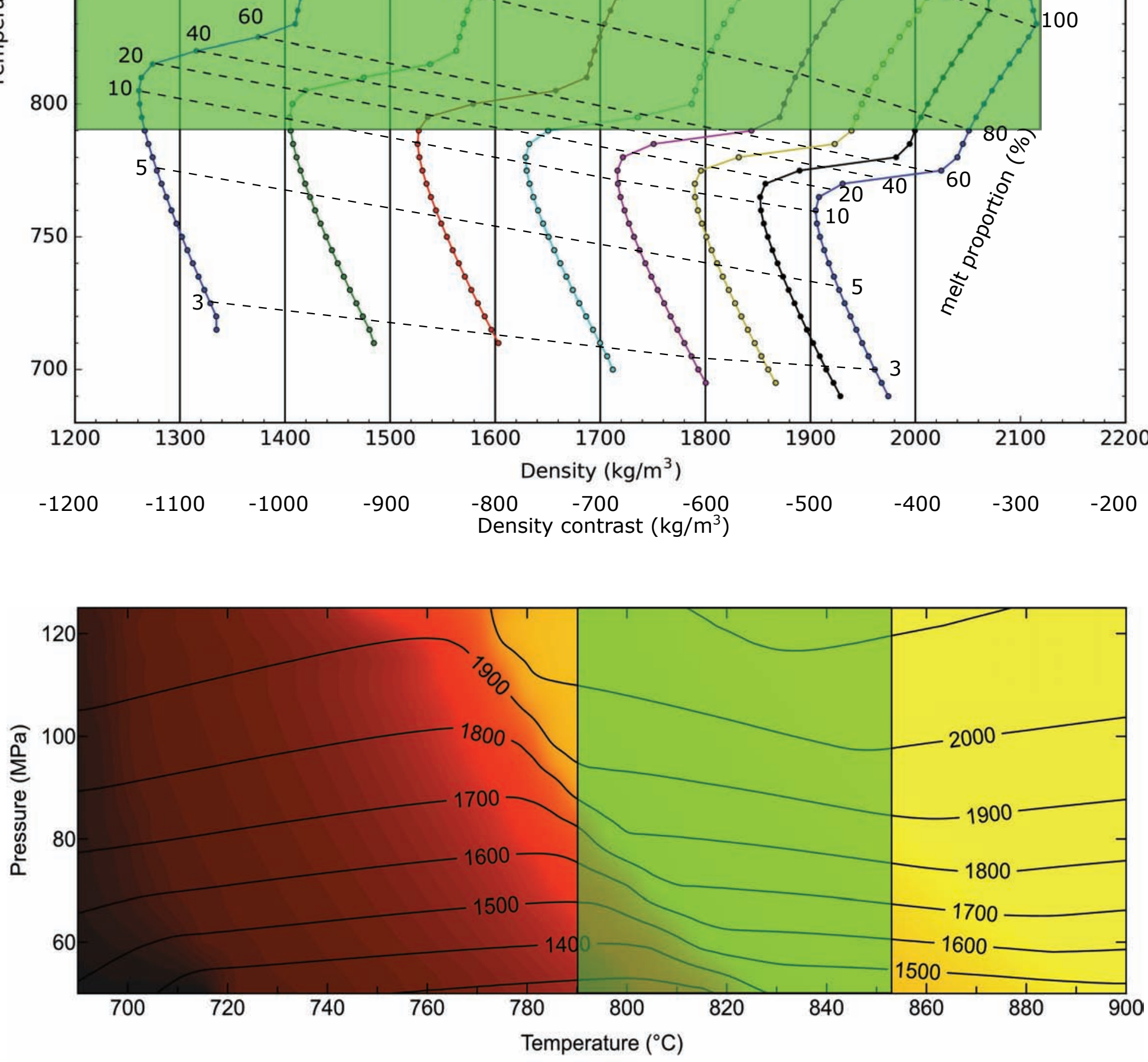

Melt \% : colour

Density $\left(\mathrm{kg} / \mathrm{m}^{3}\right)$ : contours

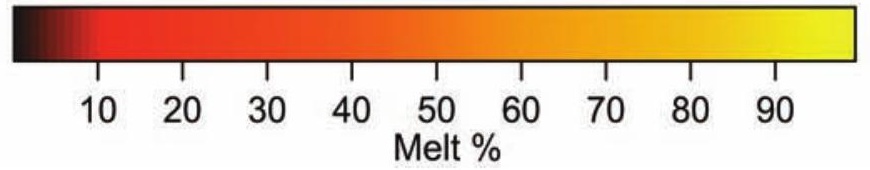


Click here to download Figure: Figure6.eps

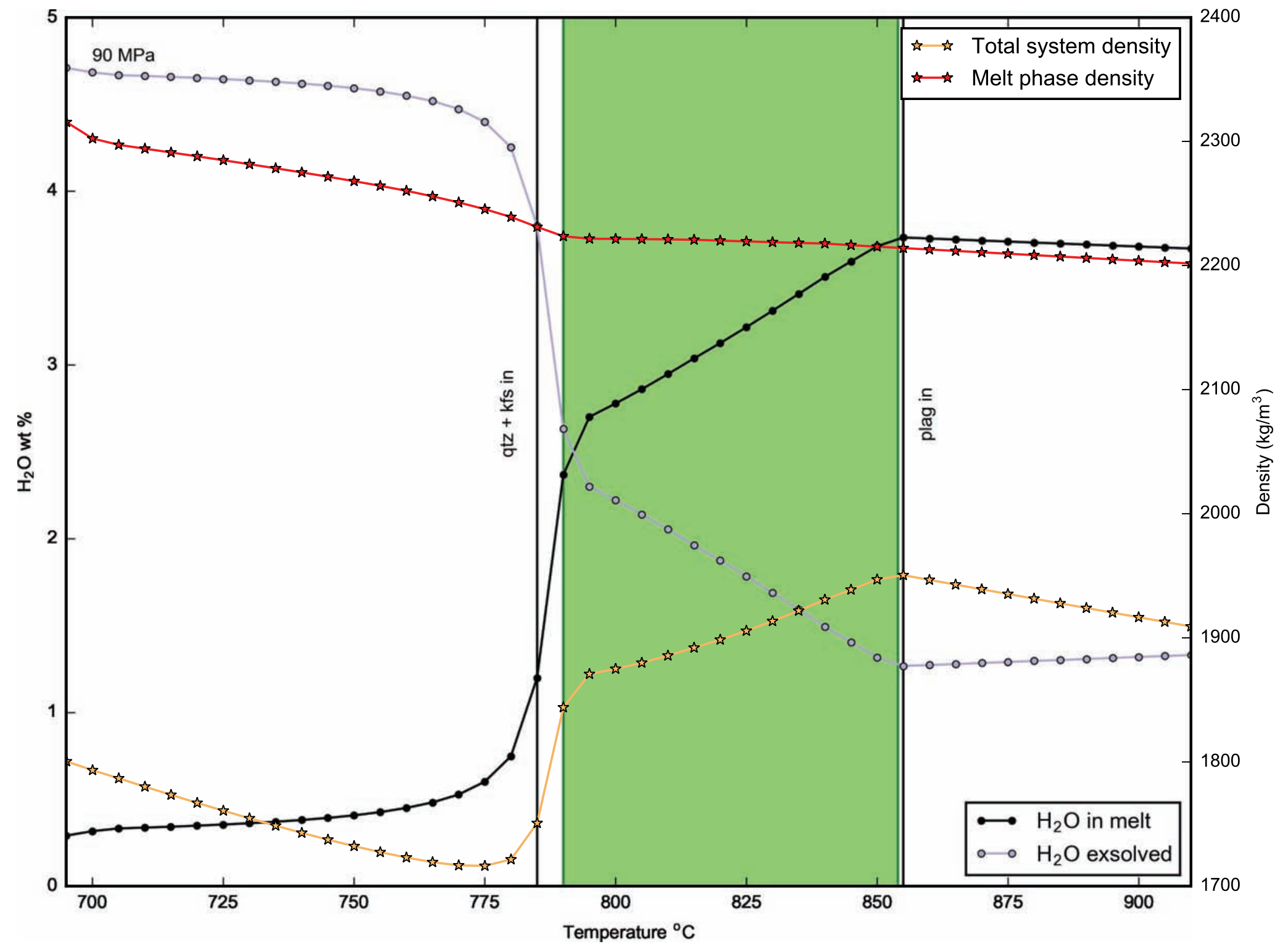




\section{Figure8}

Click here to download Figure: Figure8.eps

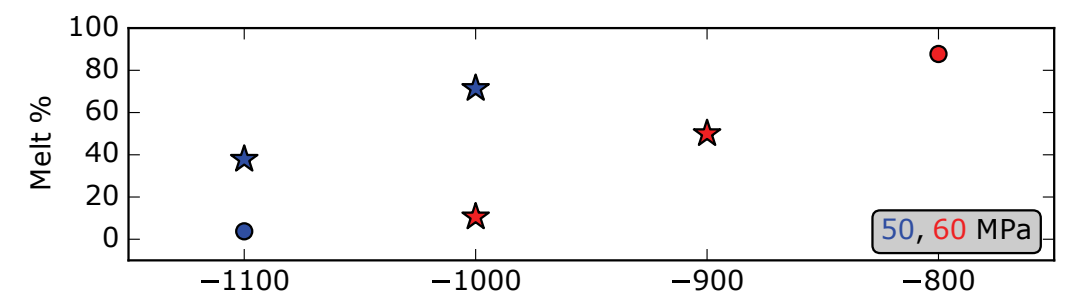

- Lower pressure model

- Higher pressure model

Preferred temperature range

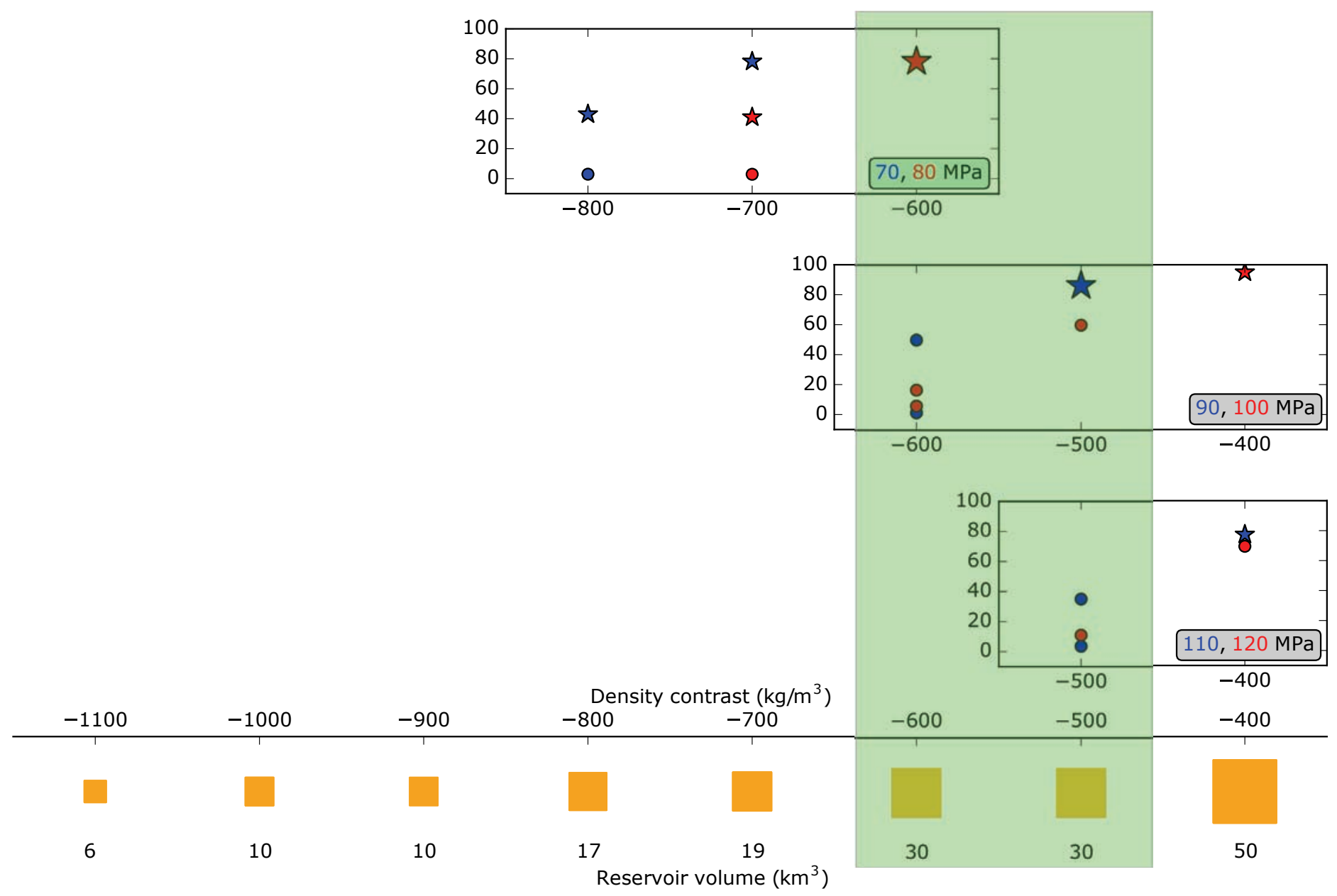




\section{Figure9}

Click here to download Figure: Figure9.eps

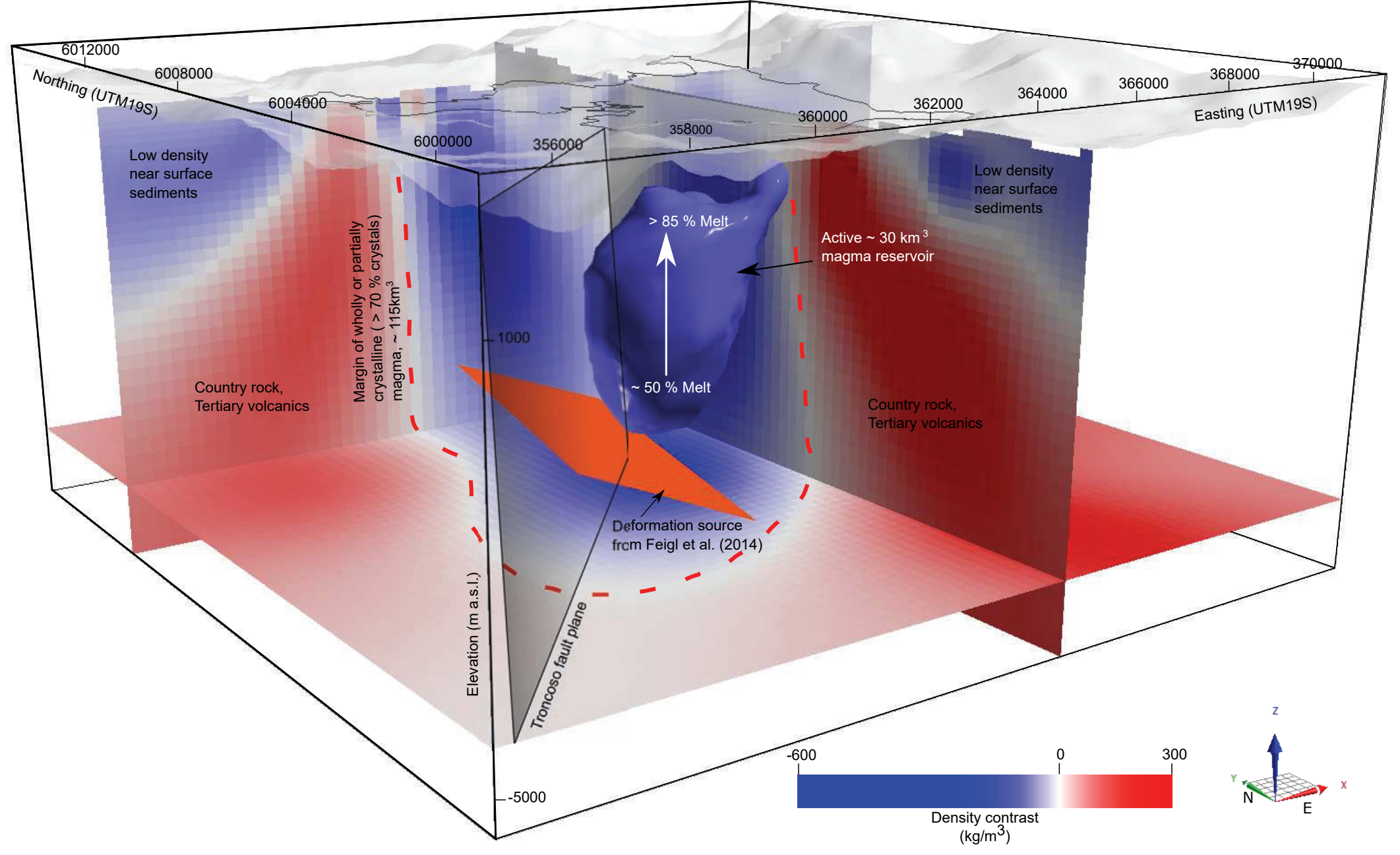



Supplementary material for online publication only
Click here to download Supplementary material for

Click here to download Supplementary material for online publication only: Supplementary material_published.pdf

(1)

(1)


LaTeX Source Files
Click here to download LaTeX Source Files: LdM_Bouguer_gravity_paper_EPSL_published.tex

LaTeX Source Files
Click here to download LaTeX Source Files: LdM_Bouguer_gravity_paper_EPSL_published.tex

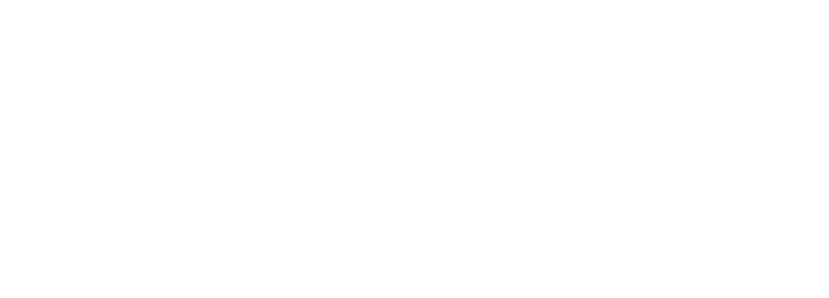

-

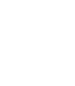

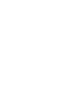

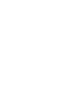

.

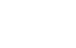

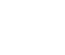

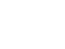

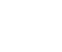

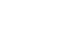

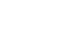

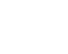

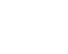

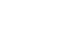

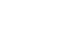

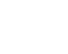

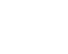

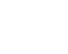

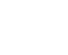

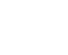

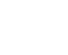

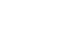

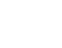

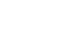

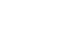

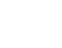

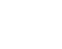

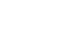

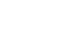

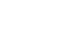

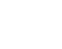

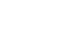

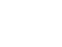

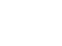

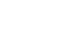

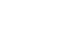

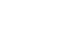



西

b

